\title{
Size distribution and ionic composition of marine summer aerosol at the continental Antarctic site Kohnen
}

\author{
Rolf Weller ${ }^{1}$, Michel Legrand ${ }^{2}$, and Susanne Preunkert ${ }^{2}$ \\ ${ }^{1}$ Glaciology Department, Alfred Wegener Institute for Polar and Marine Research, Am Handelshafen 12, 27570 \\ Bremerhaven, Germany \\ ${ }^{2}$ Université Grenoble Alpes, CNRS, Laboratoire de Glaciologie et Géophysique de l'Environnement (LGGE), \\ Grenoble, France
}

Correspondence: Rolf Weller (rolf.weller@awi.de)

Received: 27 June 2017 - Discussion started: 25 October 2017

Revised: 21 December 2017 - Accepted: 22 January 2018 - Published: 19 February 2018

\begin{abstract}
We measured aerosol size distributions and conducted bulk and size-segregated aerosol sampling during two summer campaigns in January 2015 and January 2016 at the continental Antarctic station Kohnen (Dronning Maud Land). Physical and chemical aerosol properties differ conspicuously during the episodic impact of a distinctive low-pressure system in 2015 (LPS15) compared to the prevailing clear sky conditions. The approximately 3-day LPS15 located in the eastern Weddell Sea was associated with the following: marine boundary layer air mass intrusion; enhanced condensation particle concentrations $\left(1400 \pm 700 \mathrm{~cm}^{-3}\right.$ compared to $250 \pm 120 \mathrm{~cm}^{-3}$ under clear sky conditions; mean $\pm \mathrm{SD}$ ); the occurrence of a new particle formation event exhibiting a continuous growth of particle diameters $\left(D_{\mathrm{p}}\right)$ from 12 to $43 \mathrm{~nm}$ over $44 \mathrm{~h}$ (growth rate $0.6 \mathrm{~nm} \mathrm{~h}^{-1}$ ); peaking methane sulfonate $\left(\mathrm{MS}^{-}\right)$, non-sea-salt sulfate (nss- $\mathrm{SO}_{4}^{2-}$ ), and $\mathrm{Na}^{+}$ concentrations $\left(190 \mathrm{ng} \mathrm{m}^{-3} \mathrm{MS}^{-}, 137 \mathrm{ng} \mathrm{m}^{-3} \mathrm{nss}_{-} \mathrm{SO}_{4}^{2-}\right.$, and $53 \mathrm{ng} \mathrm{m}^{-3} \mathrm{Na}^{+}$compared to $24 \pm 15,107 \pm 20$, and $4.1 \pm 2.2 \mathrm{ng} \mathrm{m}^{-3}$, respectively, during clear sky conditions); and finally an increased $\mathrm{MS}^{-} / \mathrm{nss}^{-\mathrm{SO}_{4}^{2-}}$ mass ratio $\beta_{\mathrm{MS}}$ of 0.4 up to $2.3(0.21 \pm 0.1$ under clear sky conditions $)$ comparable to typical values found at coastal Antarctic sites. Throughout the observation period a larger part of $\mathrm{MS}^{-}$ could be found in super-micron aerosol compared to nss$\mathrm{SO}_{4}^{2-}$, i.e., $(10 \pm 2) \%$ by mass compared to $(3.2 \pm 2) \%$, respectively. On the whole, under clear sky conditions aged aerosol characterized by usually mono-modal size distributions around $D_{\mathrm{p}}=60 \mathrm{~nm}$ was observed. Although our observations indicate that the sporadic impacts of coastal cyclones
\end{abstract}

were associated with enhanced marine aerosol entry, aerosol deposition on-site during austral summer should be largely dominated by typical steady clear sky conditions.

\section{Introduction}

The impact of aerosols on global climate, which is in particular mediated by governing cloud droplet concentrations and hence cloud optical properties (Rosenfeld et al., 2014; Seinfeld et al., 2016), is of crucial importance but likewise notoriously charged with the largest uncertainties (Boucher et al., 2013; Seinfeld et al., 2016). In a seminal review, Carslaw et al. (2013) concluded that uncertainties in cloud radiative forcing are inter alia caused by uncertainties in natural emissions of dimethylsulfide (DMS) producing biogenic sulfur aerosol (i.e., $\mathrm{MS}^{-}$and nss- $\mathrm{SO}_{4}^{2-}$ ) and sea spray. The radiation budget over the Southern Ocean is a particular challenge for current climate models, as they disturbingly underpredict the aerosol optical depth, pointing to a missing source of aerosols influencing cloud properties in this region (Bodas-Salcedo et al., 2014; Humphries et al., 2016). The competing role of biogenic sulfur (linked with phytoplankton presence) and otherwise sea salt aerosol (linked with stormy sea) in controlling cloudiness above the Southern Ocean is still up for debate (Meskhidze and Nenes, 2006; Korhonen et al., 2008; Quinn and Bates, 2011; Gras and Keywood, 2017).

Biogenic sulfur aerosol, i.e., secondary aerosol produced by the photooxidation of DMS and primary sea salt aerosol, by far dominate the aerosol mass over the Southern Ocean 
around Antarctica (Raes et al., 2000; Quinn and Bates, 2011). This original marine aerosol is partly transported to continental Antarctica and eventually deposited on the ice shield. Ideally, deposited aerosol constituents are archived in chronological order in firn (densified snow) and ice (Legrand and Mayewski, 1997). Therefore ice core records of biogenic sulfur and sea salt tracers potentially provide invaluable information on their (strictly speaking local) atmospheric budget, which is intrinsically tied to the Southern Ocean climate in the past (Wolff et al., 2006; Kaufmann et al., 2009; Mayewski et al., 2009; Abram et al., 2013). More specifically, investigations of sea salt and biogenic sulfur records from the EPICA (European Project for Ice Coring in Antarctica) ice core retrieved at Kohnen station in Dronning Maud Land revealed the relationship of these archived aerosol tracer profiles with climate indices such as the Antarctic Circumpolar Wave or the Antarctic Dipole (Fischer et al., 2004; Fundel et al., 2006). In view of the poor knowledge of aerosol source strength and atmospheric concentrations regarding the Southern Ocean realm, retrieving representative historic data from ice core archives is consequently desirable. Certainly, any meaningful interpretations of ice core records rely on the knowledge of the source region and major transport processes as well as transport efficiency to continental Antarctica which is connected with the instant general weather situation. These crucial points can only be elucidated by dedicated aerosol measurements on-site.

In this way, previous aerosol investigations (bulk and sometimes size-segregated composition) revealed a striking difference in the seasonality of sulfur aerosol composition between coastal and inland Antarctica, with $\mathrm{MS}^{-} / \mathrm{nss}^{-}$ $\mathrm{SO}_{4}^{2-}$ mass ratios $\left(\beta_{\mathrm{MS}}\right)$ reaching a maximum in January at the coast (0.40 at Neumayer, for instance; Legrand and Pasteur, 1998). This contrasts with midsummer $\beta_{\mathrm{MS}}$ as low as 0.2 or less at inland Antarctic sites including the South Pole (Arimoto et al., 2004) and the two deep ice core drilling sites of the EPICA project (Kohnen: Weller and Wagenbach, 2007, and Concordia: Preunkert et al., 2008, and Becagli et al., 2012). Based on an extended (2006-2015) record of aerosol, Legrand et al. (2017a) found that low values of $\beta_{\mathrm{MS}}$ in midsummer at Concordia $(0.05 \pm 0.02)$ coincided with periods of high photochemical activity as indicated by the presence of locally photochemically produced $\mathrm{O}_{3}$. This outcome strongly suggests the occurrence of an efficient chemical destruction of $\mathrm{MS}^{-}$over the Antarctic Plateau in midsummer. In addition, dedicated aerosol investigations within EPICA at Kohnen (Piel et al., 2006) have demonstrated the conspicuous impact of a cyclone on aerosol transport: in the aftermath of an intense low-pressure system over the eastern Weddell Sea region in combination with a blocking highpressure ridge to the east in early January 2002 (Birnbaum et al., 2006), $\mathrm{MS}^{-}$and nss- $\mathrm{SO}_{4}^{2-}$ aerosol entry showed an exceptional maximum (Piel et al., 2006). So far, a distinct impact of cyclones on aerosol concentrations has been frequently observed at coastal sites (e.g., Ito and Iwai, 1981, for Syowa and Pant et al., 2010, for Maitri), but only rarely on the Antarctic Plateau region (Hogan and Barnard, 1978, for the South Pole). In the most elaborate study about this topic, Pant et al. (2010) reported an almost constant background aerosol concentration under calm conditions, while during the passage of cyclones coarse-mode sea salt aerosol increased by an order of magnitude and occasionally new particle formation could be detected in the aftermath of the storms.

Up to now, all investigations at Kohnen were purely based on bulk aerosol sampling. The aim of our present study is focused on the variability of aerosol number concentration, aerosol size distribution, and size-segregated aerosol sampling to investigate the impact of different general weather situations on the physical and chemical properties of the aerosol for a site located on the Antarctic Plateau (Weller et al., 2017). This extended synoptic documentation of the physics and chemistry of Antarctic aerosol primarily concentrates on biogenic sulfur aerosol due to its distinct seasonal summer concentration peak caused by the seasonality of marine biogenic activity in the surrounding Southern Ocean (Weller and Wagenbach, 2007). Hence deposition in Dronning Maud Land should be virtually entirely governed by the atmospheric concentration maximum on-site, which was sufficiently covered by our dedicated observations.

\section{Experimental techniques and data evaluation methods}

\subsection{Site description}

During two summer seasons between 16 January and 3 February 2015 and 12 and 29 January 2016, we conducted aerosol size distribution measurements and sizesegregated aerosol samplings at the continental Kohnen station $\left(75^{\circ} 00^{\prime} \mathrm{S}, 00^{\circ} 04^{\prime} \mathrm{E}\right.$, altitude: $2892 \mathrm{~m}$ a.g.l.; http://www. awi.de/en/expedition/stations/kohnen-station.html; last access: 7 December 2017). This summer camp is the former deep ice core drilling location within the EPICA project in Dronning Maud Land about $550 \mathrm{~km}$ away from the ice shelf edge. Apart from the given internet link, another detailed description of the site comprising technical issues and a retrospect of the scientific activities can be found in Oerter et al. (2009). In order to minimize the impact of contamination from the permanently running diesel generator at the station, all experiments were installed inside (in situ measurements) or around (aerosol sampling) a bivouac hut located in the clean air sector about $250 \mathrm{~m}$ to the northeast of Kohnen (Fig. 1). The power supply $(7 \mathrm{~kW})$ was provided by cable from the main station. No fuel-driven generator was operated in the designated clean air sector (Fig. 1) and motor vehicle traffic was strictly prohibited. Contamination-free sampling was controlled by the permanently recorded wind velocity and direction. Contamination was indicated for each of the 


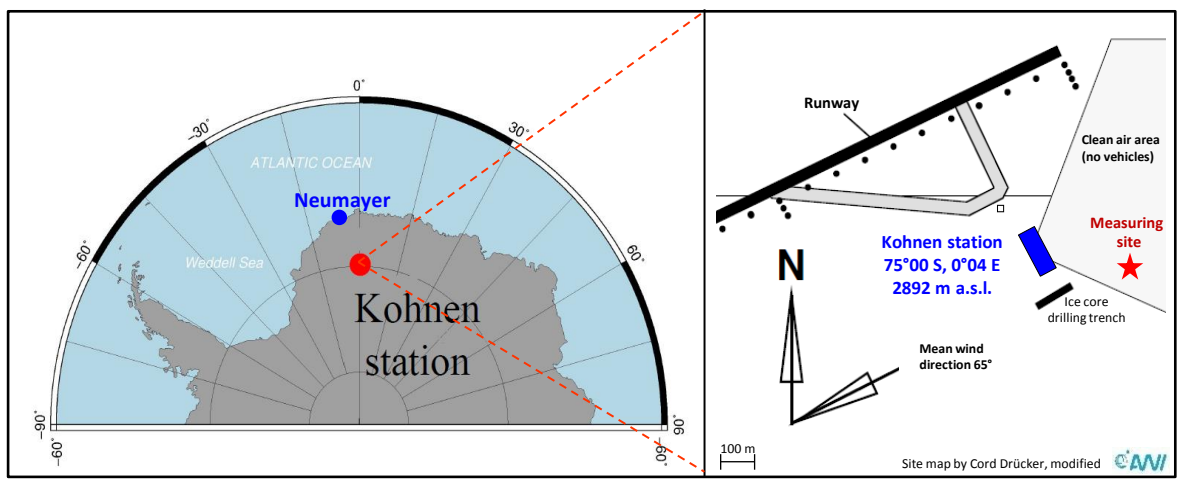

Figure 1. Location of Kohnen station (Dronning Maud Land, DML) and site plan of the station surroundings.

following criteria: wind direction within a $260-340^{\circ}$ sector and/or wind velocity $<1.5 \mathrm{~m} \mathrm{~s}^{-1}$. In the case of contamination as given by these criteria, we interrupted the aerosol sampling experiments (low volume and impactor).

For convenience we will use throughout this work the notion "day of the year" (doy) instead of the calendar date and time is indicated in UTC, which is virtually identical to the solar time. All trace compound concentrations refer to standard volume at $273 \mathrm{~K}$ and $1013 \mathrm{hPa}(\mathrm{STP})$.

\subsection{Experimental setup}

\subsubsection{Particle concentration and size distribution}

An overview of the experimental setup during both campaigns is given in Table 1, comprising the respective measuring periods of the different configurations and the relevant specifications of the deployed instruments. The size distribution of the sub-micrometer aerosol at Kohnen was determined by a scanning mobility particle sizer (SMPS; TSI classifier model 3080; Wang and Flagan, 1990). Setup and respective data evaluation methods were virtually identical to our installation run at Neumayer Station, as already described in detail elsewhere (Weller et al., 2015). Hence we simply highlight here the most relevant points. The SMPS was generally run in combination with the same condensation particle counter (TSI, model WCPC 3788; $50 \%$ cutoff diameter $D_{\mathrm{p}(50 \%)}$ of $\left.2.5 \mathrm{~nm}\right)$ controlled by the TSI software AIM (Aerosol Instrument Manager ${ }^{\circledR}$ version 9.0). The classifier was operated alternately with a so-called nano-DMA (nano-differential mobility analyzer; TSI model 3085) and a DMA model 3081. Equipped with the nano-DMA 3085, we adjusted the aerosol and sheath flow of the classifier to achieve nominal aerosol size distribution measurements between 2 and $64 \mathrm{~nm}$, while in use with the DMA 3081, flows were adjusted to cover the size range between 10 and $420 \mathrm{~nm}$ (in both cases with 64 channel resolution). Both DMA types were operated with a scanning time of $120 \mathrm{~s}$ (retrace time $15 \mathrm{~s}$ ) and the average size distribution of four consecutive (multiple charge and diffusion corrected) spectra was finally evaluated, resulting in a temporal resolution of $600 \mathrm{~s}$.

Particle size distributions were complemented with continuous condensation particle $(\mathrm{CP})$ concentration measurements (TSI, model CPC 3775; $D_{\mathrm{p}(50 \%)}$ of $4 \mathrm{~nm}$ in 2015 and CPC 3025A, $D_{\mathrm{p}(50 \%)}$ of $3 \mathrm{~nm}$ in 2016). Below, we will use the terms nucleation mode for particles with $D_{\mathrm{p}}<25 \mathrm{~nm}$ and Aitken mode for the size range between 25 and $100 \mathrm{~nm}$ (Dal Maso et al., 2005).

\subsubsection{Low-volume and impactor aerosol sampling}

The low-volume sampler (ISAP ${ }^{\circledR} 1050$; Schulze Automatisierungstechnik, Germany) and the five-stage low-pressure Berner-type impactor (GIV, model 80/0.05/2.88) were installed outdoors ca. $15 \mathrm{~m}$ northeast of the bivouac hut with ambient air inlets about $1.70 \mathrm{~m}$ above the ground. Low-volume sampling $\left(1.66 \mathrm{~m}^{3} \mathrm{~h}^{-1}\right.$ (STP), face velocity $0.33 \mathrm{~m} \mathrm{~s}^{-1}$ ) was regularly conducted in $24 \mathrm{~h}$ time periods, while the impactor was run with a flow rate of $4.74 \mathrm{~m}^{3} \mathrm{~h}^{-1}$ (STP) in 2-day or 3-day intervals (Table 1; sample exchange usually in the early afternoon around 14:00). For bulk aerosol sampling with the low-volume sampler we used a Teflon and a nylon (Nylasorb) filter in series (Pall Corp.; $47 \mathrm{~mm}$ diameter and $1 \mu \mathrm{m}$ pore size). The low-volume sampling procedure and filter handling was the same as in our Kohnen campaigns in 2001 and 2002, as described in Piel et al. (2006). The impactor was equipped with Tedlar foils (Hauke GmbH, Austria) and the aerodynamic cutoffs of the stages were corrected for ambient conditions according to the Stokes law (Table 1).

According to Piel et al. (2006) sample extracts were analyzed by using ion chromatography (IC) for methane sulfonate $\left(\mathrm{CH}_{3} \mathrm{SO}_{3}^{-}, \mathrm{MS}^{-}\right), \mathrm{Cl}^{-}, \mathrm{Br}^{-}, \mathrm{NO}_{3}^{-}, \mathrm{SO}_{4}^{2-}, \mathrm{Na}^{+}, \mathrm{NH}_{4}^{+}$, $\mathrm{K}^{+}, \mathrm{Mg}^{2+}$, and $\mathrm{Ca}^{2+}$. The nss- $\mathrm{SO}_{4}^{2-}$ part was calculated using the sea salt tracer $\mathrm{Na}^{+}$according to Piel et al. (2006). Unfortunately, due to unbearable nitrate blanks (caused by an unperceived and unauthorized use of nitric acid in the IC laboratory), all measured $\mathrm{NO}_{3}^{-}$concentrations were treated as meaningless and discarded. In addition, $\mathrm{Br}^{-}, \mathrm{K}^{+}, \mathrm{Mg}^{2+}$, 
Table 1. Survey of the experimental setup during both summer campaigns at Kohnen station.

\begin{tabular}{|c|c|c|}
\hline Measured parameter & $\begin{array}{l}\text { Summer campaign } 2015 \\
\text { (between } 16 \text { Jan and } 3 \text { Feb 2015) }\end{array}$ & $\begin{array}{l}\text { Summer campaign } 2016 \\
\text { (between } 12 \text { Jan and } 29 \text { Jan 2016) }\end{array}$ \\
\hline Particle number concentration & $\begin{array}{l}\text { CNC } 3775(\mathrm{TSI}) \text {, } \\
\text { cutoff } D_{\mathrm{p}(50 \%)}=4 \mathrm{~nm} ; 60 \mathrm{~s} \text { resolution }\end{array}$ & $\begin{array}{l}\text { CNC } 3025 \mathrm{~A}(\mathrm{TSI}) \\
\text { cutoff } D_{\mathrm{p}(50 \%)}=3 \mathrm{~nm} ; 60 \text { s resolution }\end{array}$ \\
\hline Particle size distribution & $\begin{array}{l}\text { SMPS 3936/WCPC } 3788 \text { (TSI); } 10 \text { min res. } \\
\text { 1. nano-DMA } 3085 \text { (TSI), } \\
\text { range (nominal): } 2 \text { to } 64 \mathrm{~nm} \text {, } \\
\text { measuring period: } 16 \text { Jan to } 27 \text { Jan } \\
\text { 2. long DMA } 3081 \text { (TSI), } \\
\text { range (nominal): } 10 \text { to } 420 \mathrm{~nm} \text {, } \\
\text { measuring period: } 27 \text { Jan to } 2 \text { Feb }\end{array}$ & $\begin{array}{l}\text { SMPS 3936/WCPC } 3788 \text { (TSI); } 10 \text { min res. } \\
\text { 1. nano-DMA } 3085 \text { (TSI) } \\
\text { Range (nominal): } 2 \text { to } 64 \mathrm{~nm} \\
\text { Measuring period: } 12 \text { to } 23 \mathrm{Jan} \\
\text { 2. long DMA } 3081 \text { (TSI), } \\
\text { range (nominal): } 10 \text { to } 420 \mathrm{~nm} \text {, } \\
\text { measuring period: } 23 \text { to } 28 \mathrm{Jan}\end{array}$ \\
\hline Bulk aerosol sampling & $\begin{array}{l}\text { Teflon-nylon filter combination, } \\
\text { about } 24 \text { or } 48 \text { h sampling intervals }\end{array}$ & $\begin{array}{l}\text { Teflon-nylon filter combination, } \\
\text { about } 24 \mathrm{~h} \text { sampling interval }\end{array}$ \\
\hline Size-segregated aerosol sampling & $\begin{array}{l}\text { Five-stage Berner-type impactor: } \\
\text { cutoff }(\mu \mathrm{m}): 3.5,1.2,0.4,0.12,0.042, \\
\text { about } 48 \text { or } 72 \mathrm{~h} \text { sampling intervals }\end{array}$ & $\begin{array}{l}\text { Five-stage Berner-type impactor: } \\
\text { cutoff }(\mu \mathrm{m}): 3.5,1.2,0.4,0.12,0.042, \\
\text { about } 48 \text { or } 72 \mathrm{~h} \text { sampling interval }\end{array}$ \\
\hline Meteorology & $\begin{array}{l}\text { Weather transmitter WXT520 (Vaisala), } \\
U, D, T, P, \mathrm{RH} ; 60 \text { s resolution }\end{array}$ & $\begin{array}{l}\text { Weather transmitter WXT520 (Vaisala), } \\
U, D, T, P, \mathrm{RH} ; 60 \text { s resolution }\end{array}$ \\
\hline
\end{tabular}

and $\mathrm{Ca}^{2+}$ concentrations were frequently close to the analytical detection limit (DL) of around $0.2 \mathrm{ng} \mathrm{m}^{-3}$. Figure 2 summarizes the overall experimental uncertainty and ascertained DL, which are valid for the main ionic compounds to be discussed below. The circles are representative percentage error at different concentrations above the given DL $\left(\xi_{i}\right)$ considering both the analytical (filter handling and IC) accuracy and the uncertainty of the sampling volume $(< \pm 5 \%)$. By using this procedure the error close to the DL was typically $\pm 25 \%$ for all ions. The DL was derived from dedicated procedure blanks (in total 10 blanks for low-volume sampling and 4 for each impactor stage) to be 3 times the standard deviation of these blanks. The blue line is an exponential fit through the values. Above a concentration of around $10 \mathrm{ng} \mathrm{m}^{-3}$, the uncertainty was mainly governed by the concentrationindependent volume ascertainment of around $\pm 5 \%$.

The original concentration data from the different impactor stages were inverted according a procedure described in Winklmayr et al. (1990). In order to assess the validity of the inversion algorithm, we first compared the mass balance of the original with the inverted data. The discrepancy was typically within 1 to $2 \%$ by mass, but never exceeds $5 \%$. Next we had to consider the influence of the analytical uncertainty of the ion concentrations on the inversion procedure. To this end we ran a Monte Carlo simulation, i.e., 1000 realizations of the inversion for a given compound were calculated, independently varying the concentrations of each impactor stage within 2 SD of the experimental error (we used individual concentration-dependent errors derived from the exponential fit in Fig. 2). From these 1000 realizations, the mean size distribution and the confidence intervals

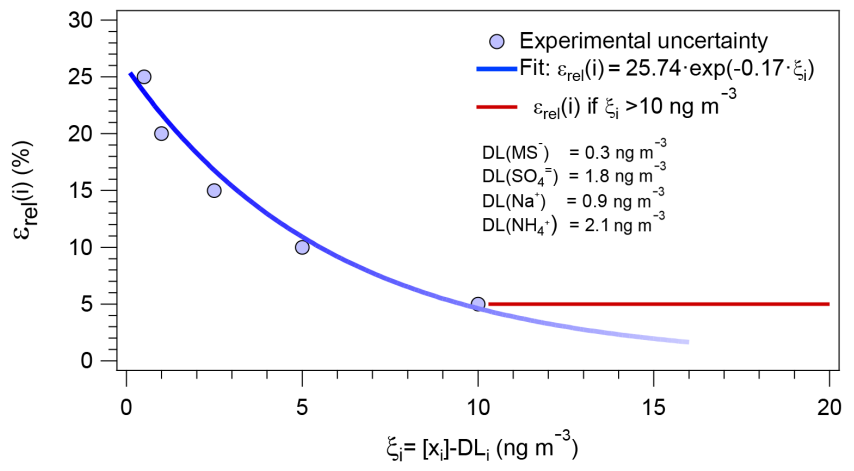

Figure 2. Relative uncertainty $\varepsilon_{\text {rel }}(i)$ of the ion measurements derived from bulk (low volume) and size-segregated (Berner impactor) sampling as a function of $\xi_{i}$. The circles represent the percentage error at different concentrations $\xi_{i}$, i.e., the measured concentration of the ion $\left[x_{i}\right]$ minus the corresponding $\mathrm{DL}_{i}$. The blue line is an exponential fit through these values. Above a concentration of around $10 \mathrm{ng} \mathrm{m}^{-3}$, the uncertainty was mainly governed by the concentration-independent volume ascertainment of around $5 \%$ (red horizontal line).

were determined. The result for the two most critical cases is shown in the Supplement (Fig. S1). For clarity, we refrain below from displaying confidence intervals in the presented impactor data.

Comparing ionic concentrations derived from low-volume and impactor sampling (including results from both campaigns covering the same sampling period, i.e., 11 out of 12 impactor samples), we found that concentration ratios from the impactor versus low-volume sampling were 


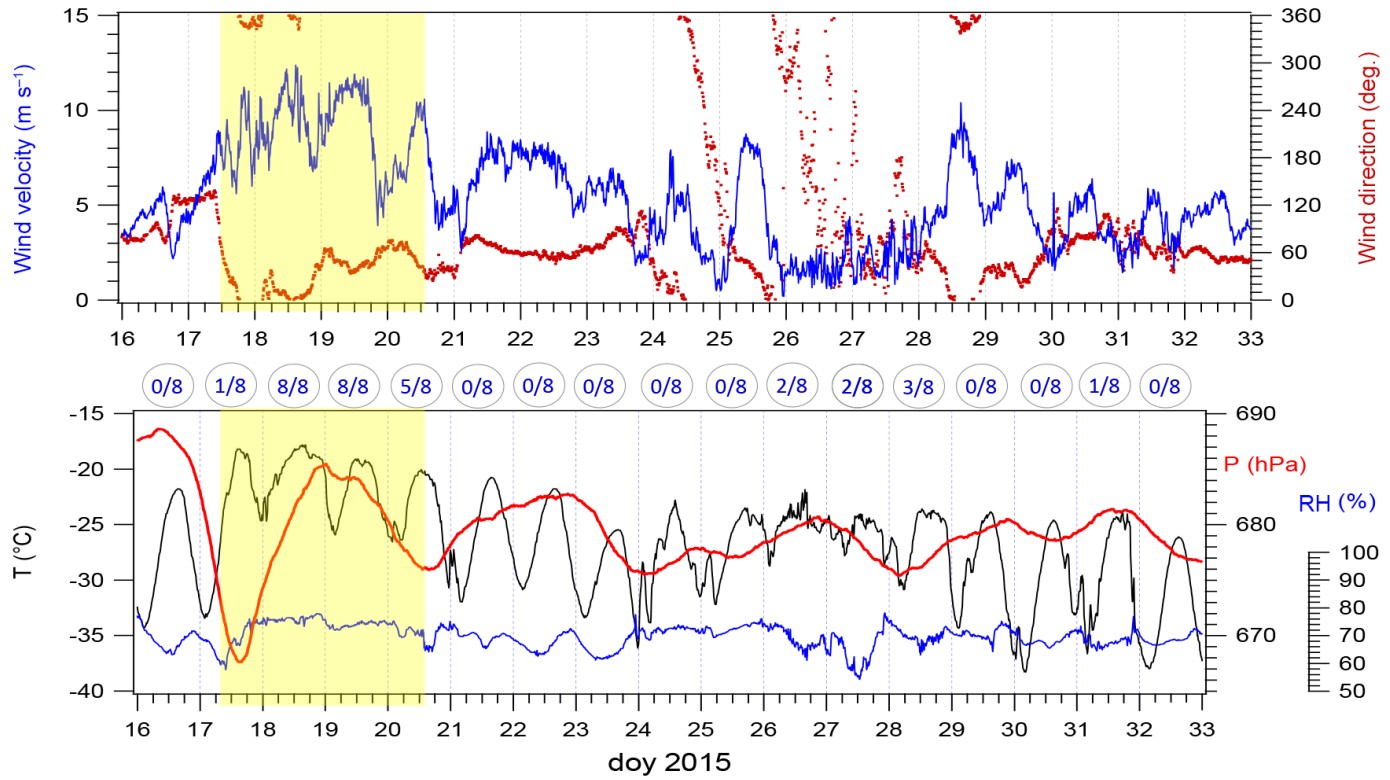

Figure 3. Time series of the measured meteorological parameters in 2015 (60s temporal resolution). The period of LPS15 is shaded in yellow. The cloud amount in oktas is denoted on the top of the second figure based on casual visual inspection.

$0.64 \pm 0.15$ for $\mathrm{MS}^{-}, 0.79 \pm 17$ for nss $-\mathrm{SO}_{4}^{2-}, 1.1 \pm 0.2$ for $\mathrm{Na}^{+}, 0.96 \pm 0.4$ for $\mathrm{Cl}^{-}$, and $0.72 \pm 0.5$ for $\mathrm{NH}_{4}^{+}$. The somewhat low sampling efficiency of the impactor for $\mathrm{MS}^{-}$may be due to partial reevaporation from the Tedlar foils (Teinilä et al., 2014). Finally, denuder experiments conducted by Piel et al. (2006) demonstrated that spurious post-sampling reactions like mobilization of volatile acids could generally be regarded as negligible for Teflon-nylon filter combinations.

\subsubsection{Meteorological measurements and backward trajectories}

The basic meteorological parameters wind speed $(U)$ and wind direction $(D)$, temperature $(T)$, barometric pressure $(P)$, and relative humidity $(\mathrm{RH})$ were measured in $60 \mathrm{~s}$ resolution by a compact automatic weather station (Vaisala Weather Transmitter WXT520). The origin and pathway of the air masses advected to the measuring site was assessed by backward trajectories (HYSPLIT 4.0, Hybrid Single-Particle Lagrangian Integrated trajectory; http://www.arl.noaa.gov/ documents/reports/hysplit_user_guide.pdf; last access: 7 December 2017) relying on GDAS meteorological data with a spatial resolution of $1^{\circ} \times 1^{\circ}$ (longitude $\times$ latitude grid). The accuracy of back trajectories is generally dependent on the availability of reliable meteorological data and their spatial coverage, which is of particular concern for remote regions like the Southern Ocean and Antarctica (see, e.g., the review by Stohl, 1998). As for coastal site Neumayer we already discussed this point (Weller et al., 2014, 2015), but for continental Antarctica, the persisting surface inversions and katabatic winds pose additional challenges to air mass tra- jectory analyses. Though a detailed accuracy assessment is beyond the scope this work, we tried to validate the consistency of the back trajectories used by (i) using the 3-D wind fields of the GDAS data and the isentropic approximation, which could be more reliable for regions with sparse meteorological input data (Harris et al., 2005); (ii) varying the starting height above the ground between 10 and $100 \mathrm{~m}$; and (iii) calculating trajectory ensembles whose starting points were varied by $\pm 1^{\circ}$ longitude and $\pm 1^{\circ}$ latitude each, while for the height above the ground 0,250 , and $500 \mathrm{~m}$ were chosen. The impact of these different initial conditions on our conclusions will be appraised in the Discussion section. Finally, weather charts generated by the Antarctic Mesoscale Prediction System (AMPS) were used to assess the general weather situation (Powers et al., 2003; http://www2.mmm. ucar.edu/rt/amps/information/amps_esg_data_info.html; last access: 7 December 2017).

\section{Results}

\subsection{Meteorological conditions}

Figures 3 and 4 give a detailed synopsis of the measured meteorological parameters. Regarding local meteorology, bright weather conditions, i.e., clear sky conditions with a cloud amount typically well below 2 oktas, prevailed, except the period between 17 and 20 January 2015 (doy 17 at 12:00 to doy 20 at 18:00) when the impact of a cyclone (LPS15) with a center in the southeastern Weddell Sea reached the site (a corresponding weather chart is shown in Fig. S2). Note that the cloud amounts given in Figs. 3 and 4 were assessed by 


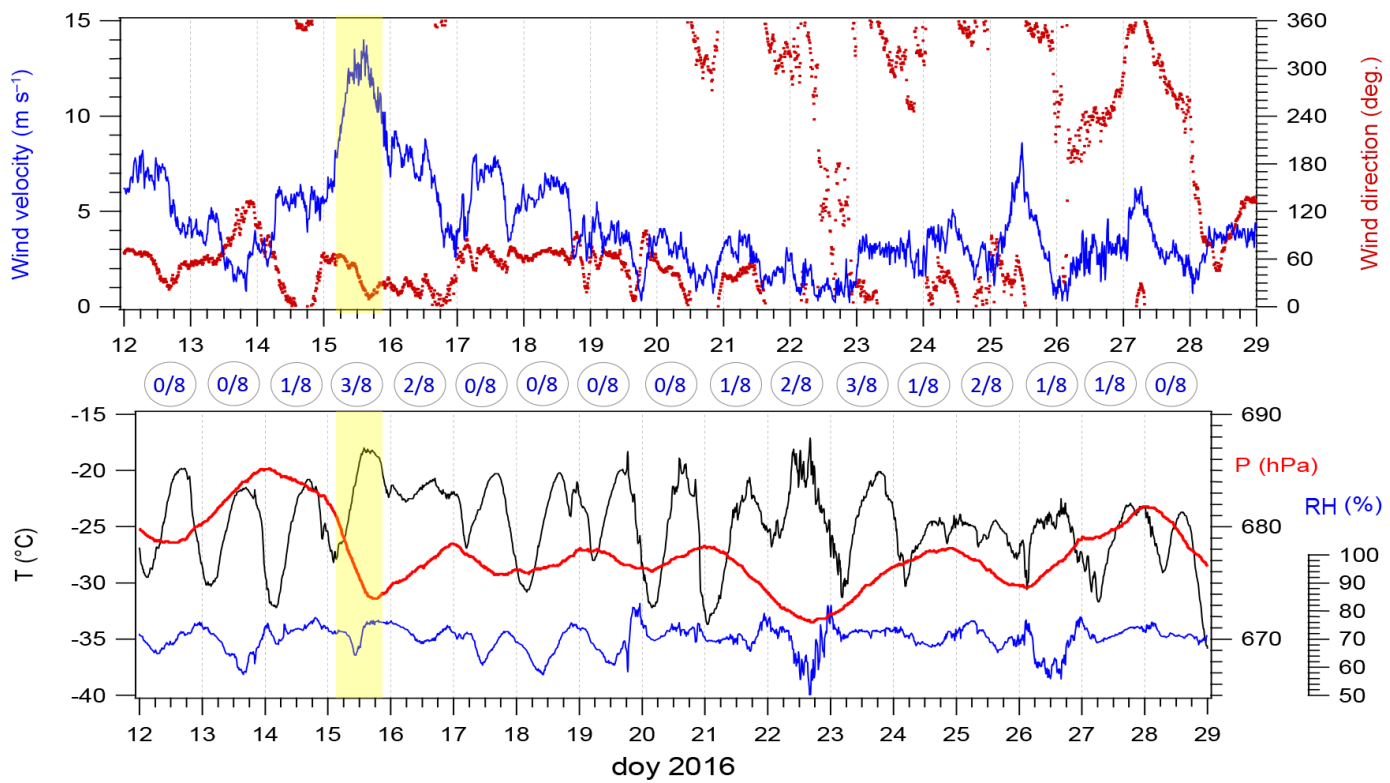

Figure 4. Time series of the measured meteorological parameters in 2016 (60 s temporal resolution). The stormy period LPS16 is shaded in yellow. Again, the cloud amount is denoted on the top of the second figure.

everyday casual visual inspection between 04:00 and 22:00 and should be rated as subjective but reasonable estimates. In the following we will especially focus on this episodic and prominent weather situation, which is preluded by a sharp pressure drop of $15 \mathrm{hPa}$ and associated with increasing wind velocities to around $10 \mathrm{~m} \mathrm{~s}^{-1}$, drifting snow, overcast sky, and some snow precipitation (which was notoriously difficult to distinguish from drifting snow). Corresponding HYSPLIT calculations predicted only marginal local precipitation around $0.2 \mathrm{~mm}$ water equivalent in the evening on $19 \mathrm{Jan}-$ uary 2015. A second prominent high wind event occurred on 15 January 2016 (LPS16; Figs. 4 and S3), again induced by an intense low-pressure system in the Weddell Sea region. In both cases the nearby coastal site Neumayer $\left(70^{\circ} 39^{\prime} \mathrm{S}\right.$, $8^{\circ} 15^{\prime} \mathrm{W}$ ) experienced severe blizzards with wind velocities up to $25 \mathrm{~m} \mathrm{~s}^{-1}$. But in contrast to LPS15, the sky was then only temporarily overcast in the case of LPS16 at Kohnen and no precipitation has been realized.

During the continuous clear sky conditions, katabatic winds from the northeast (following the terrain slope) around $5 \mathrm{~m} \mathrm{~s}^{-1}$, usually with a maximum shortly after midnight and a minimum in the late afternoon, were typical. Frequently, sparse clear sky precipitation (diamond dust) could be observed during night and early morning. In such cases, AMPS weather charts revealed only shallow low-pressure systems offshore of DML and the characteristic continental anticyclone centered some hundred kilometers east or southeast from Kohnen, which was also present during LPS15 and LPS16 (Figs. S2 and S3).

Due to our limited meteorological database, a thorough characterization of the atmospheric boundary layer was not feasible. Though to this end it seems reasonable to access a detailed investigation of the summertime atmospheric boundary layer at Kohnen by Van As et al. (2006). Concerning clear sky conditions, our meteorological conditions $(U, D, T$, and $P$ ) were virtually comparable to a 4-day period described therein. Hence, according to Van As et al. (2006), we may assume the presence of a stable boundary layer overnight with strong temperature inversion (typically around $5 \mathrm{~K} \mathrm{~m}^{-1}$ and a thickness up to $50 \mathrm{~m}$ ), developing to a slightly convective layer (up to $50 \mathrm{~m}$ thick) around noon with near-neutral stability and capped by an inversion layer (Van As et al., 2006).

\subsection{Particle concentrations and related size distributions}

In Figs. 5 and 6, CP concentrations measured with both CPCs $\left(\mathrm{CP}_{4 \mathrm{~nm}}\right.$ and $\mathrm{CP}_{3 \mathrm{~nm}}$ during 2015 and 2016, respectively) along with the ultrafine particle concentrations between 3 and $25 \mathrm{~nm}\left(\mathrm{UCP}_{3-25}\right)$ and between 10 and $25 \mathrm{~nm}\left(\mathrm{UCP}_{10-25}\right)$ are displayed. CP concentrations were strikingly enhanced during LPS15 (1400 $\pm 700 \mathrm{~cm}^{-3}$ compared to $250 \pm 120 \mathrm{~cm}^{-3}$ during clear sky conditions), though on the whole clearly lower compared to coastal sites like Neumayer (Weller et al., 2011). Both UCP time series were derived from the nanoDMA 3085 and DMA 3081 data, which are conflated as contour plots in Figs. 7 and S4-S6. The striking feature was the strong rise in $\mathrm{CP}$, most notably $\mathrm{UCP}_{3-25}$ concentrations, during the onset of LPS15. This period was characterized by elevated $\mathrm{UCP}_{3-25} / \mathrm{CP}_{4 \mathrm{~nm}}$ ratios of $0.75 \pm 0.5$. After a recurring weather situation, i.e., the remaining observation period 

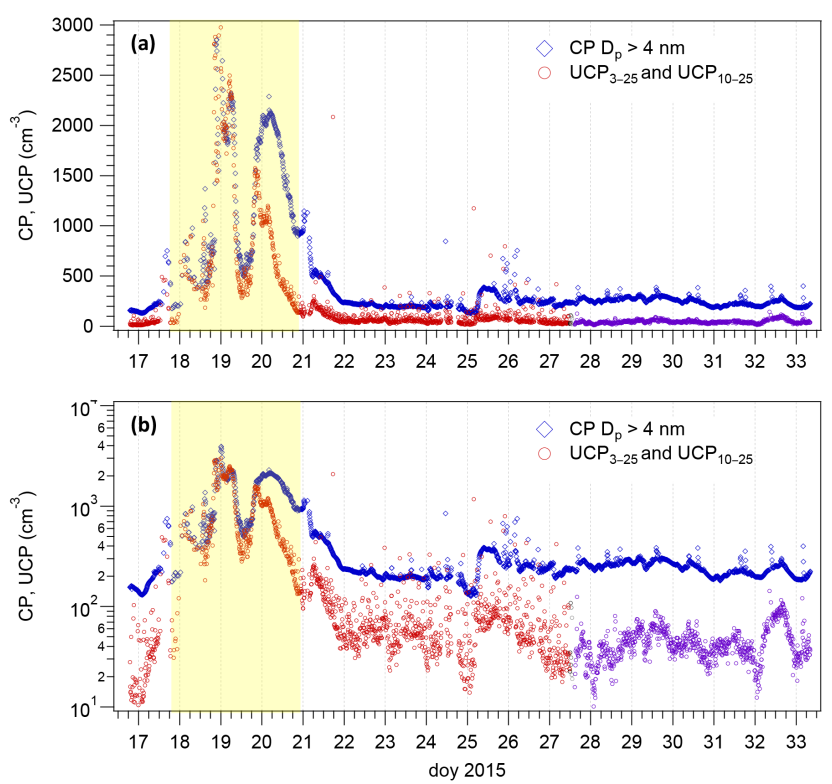

Figure 5. CP (blue diamonds), $\mathrm{UCP}_{3-25}$ (red circles), and $\mathrm{UCP}_{10-25}$ (purple circles) concentration time series (10 min resolution) during the campaign 2015 . $\mathrm{UCP}_{3-25}$ and $\mathrm{UCP}_{10-25}$ values were derived from the nano-DMA 3085 and DMA 3081 data, respectively. The period of LPS15 is shaded in yellow.

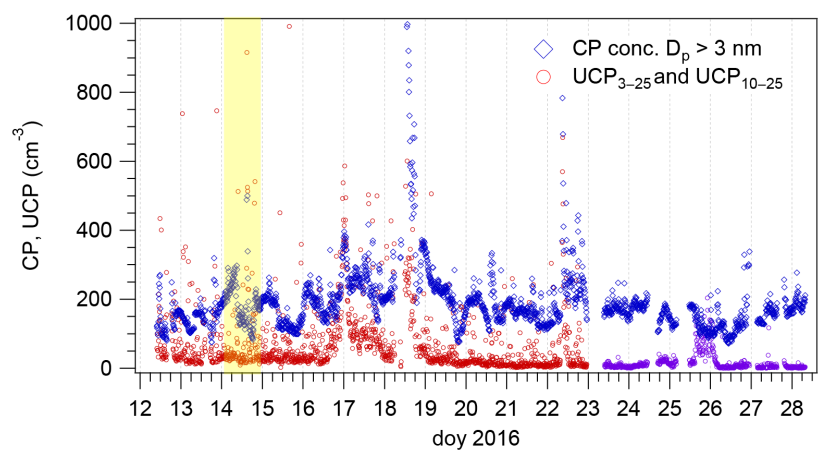

Figure 6. $\mathrm{CP}$ (blue diamonds), $\mathrm{UCP}_{3-25}$ (red circles), and $\mathrm{UCP}_{10-25}$ (purple circles) concentration time series (10 min resolution) during the campaign 2016. The period of the LPS16 is shaded in yellow.

in 2015 and throughout the campaign in 2016, including the stormy period LPS16, UCP / CP ratios were typically below 0.3 (more precisely: $\mathrm{UCP}_{3-25} / \mathrm{CP}_{4} \mathrm{~nm}$ and $\mathrm{UCP}_{3-25} / \mathrm{CP}_{3 \mathrm{~nm}}$ stayed around $0.28 \pm 0.2$, while $\mathrm{UCP}_{10-25} / \mathrm{CP}_{4 \mathrm{~nm}}$ and $\mathrm{UCP}_{10-25} / \mathrm{CP}_{3 \mathrm{~nm}}$ were $0.18 \pm 0.07$ and $0.11 \pm 0.1$, respectively, Figs. 5 and 6). Table 2 summarizes particle concentrations and the ionic composition of the aerosol during the impact of LPS15, LPS16, and clear sky conditions. While during 2015 CPC and UCP concentrations were nearly an order of magnitude higher compared to clear sky conditions, the effect of LPS16 was not obvious.

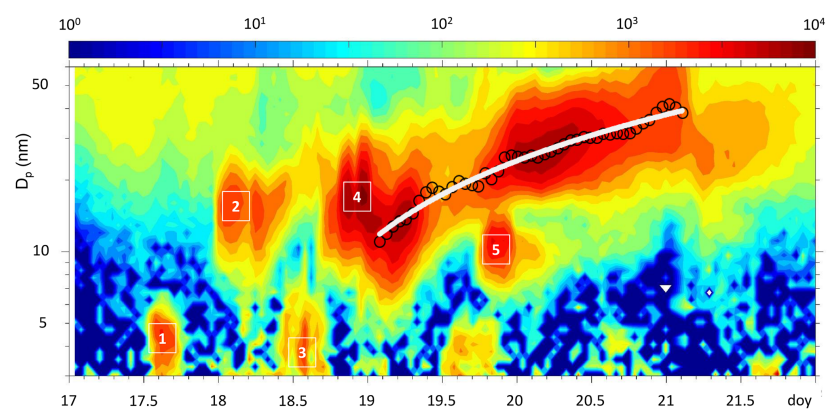

Figure 7. Time series of the particle size distribution $\mathrm{d} N / \mathrm{d} \log D_{\mathrm{p}}$ $\left(\mathrm{cm}^{-3}\right)$ on a logarithmic scale (color code at the top of the contour plot), including the NPF event and measured with the nanoDMA 3085. Particle growth is displayed as a bold white line derived from lognormal distribution fits through size distributions measured between 19 January at 02:55 and 20 January at 24:00. The black circles represent the fitted mode mean diameters. Periods with enhanced UCP concentrations and nucleation bursts are numbered.

Expectedly, the time series of the particle number size distributions (PNSDs) exhibited a corresponding distinct feature (Fig. 7): during LPS15, we observed according to Dal Maso et al. (2005) a pronounced class 1 or so-called "bananatype" NPF event. Particle growth started at doy 19 (02:50) at a modal maximum of $12 \mathrm{~nm}$, reaching $43 \mathrm{~nm}$ at doy 20 (24:00; Fig. 7). While CP and UCP concentrations exhibited distinct breaks around noon at doy 19 (Fig. 5), steady particle growth was observed throughout. The initial nucleation particle formation rate (doy 19 between 02:50 and 17:20) in the size range 3 to $25 \mathrm{~nm}\left(J_{3-25}=\Delta \mathrm{UCP}_{3-25} / \Delta t\right)$ was around $0.1 \mathrm{~s}^{-1}$. The shape of the size distributions during this NPF event were "closed" (i.e., decreasing from the modal maxima towards the lowest size bin at $3 \mathrm{~nm}$ ). From their temporal evolution we derived a continuous growth rate of $0.6 \pm 0.08 \mathrm{~nm} \mathrm{~h}^{-1}$ for the whole event between doy 19 (02:50) and doy 20 (24:00). In addition, a separate calculation for the first and second part of the event (boundary: noon on doy 19) resulted in virtually identical growth rates of $0.6 \pm 0.1 \mathrm{~nm} \mathrm{~h}^{-1}$ for both sections. A condensation sink of typically around $(2.0 \pm 0.2) \times 10^{-4} \mathrm{~s}^{-1}$ was calculated according to Kulmala et al. (2001) from SMPS data when operated with DMA 3081, covering the extended size range between 10 and $420 \mathrm{~nm}$.

In addition, we observed enhanced UCP concentrations between 10 and $25 \mathrm{~nm}$ during doy 18 in the morning hours, just before the actual NPF, and in the evening on doy 19 (numbered 2, 4, and 5 in Fig. 7). Apart from that, discernible natural nucleation bursts occurred around noon on doy 17 and 18 (numbered 1 and 3 in Fig. 7). All these transient UCP maxima did not show any detectable particle growth. The nucleation bursts were characterized by increasing particle concentrations from slightly above $5 \mathrm{~nm}$ downward towards the lower instrumental size limit ("open" distribution), indicating local nucleation. Table 3 provides a summary of the 
Table 2. Particle number concentrations and ionic composition (mean \pm SD) classified into different general weather conditions (impact of low-pressure system and clear sky conditions during both campaigns); note that the ionic composition during LPS16 was based on one sample, and hence no SD can be given. NA - not available.

\begin{tabular}{lrrrr}
\hline Measured parameter & \multicolumn{2}{c}{$\begin{array}{c}\text { Summer campaign 2015 } \\
\text { LPS15 clear sky cond. }\end{array}$} & \multicolumn{2}{c}{$\begin{array}{c}\text { Summer campaign 2016 } \\
\text { LPS16 clear sky cond. }\end{array}$} \\
\hline $\mathrm{CPC}_{4 \mathrm{~nm}}\left(\mathrm{~cm}^{-3}\right)$ & $1400 \pm 700$ & $250 \pm 120$ & $\mathrm{NA}$ & $\mathrm{NA}$ \\
$\mathrm{CPC}_{3 \mathrm{~nm}}\left(\mathrm{~cm}^{-3}\right)$ & $\mathrm{NA}$ & $\mathrm{NA}$ & $150 \pm 40$ & $200 \pm 120$ \\
$\mathrm{UCP}_{3-25 \mathrm{~nm}}\left(\mathrm{~cm}^{-3}\right)$ & $880 \pm 730$ & $90 \pm 100$ & $57 \pm 100$ & $120 \pm 164$ \\
$\mathrm{UCP}_{10-25 \mathrm{~nm}}\left(\mathrm{~cm}^{-3}\right)$ & $\mathrm{NA}$ & $46 \pm 24$ & $\mathrm{NA}$ & $18 \pm 30$ \\
$\mathrm{MS}^{-}\left(\mathrm{ng} \mathrm{m}^{-3}\right)$ & $111 \pm 70$ & $14.8 \pm 3.7$ & 73.6 & $26 \pm 19$ \\
$\mathrm{nss}_{-} \mathrm{SO}_{4}^{2}\left(\mathrm{ng} \mathrm{m}^{-3}\right)$ & $96 \pm 35$ & $81 \pm 9$ & 181 & $115 \pm 24$ \\
$\beta_{\mathrm{MS}^{-}\left(\mathrm{MS}^{-} / \mathrm{nss}^{-} \mathrm{SO}_{4}^{2-}\right)}$ & $1.14 \pm 0.8$ & $0.18 \pm 0.03$ & 0.41 & $0.22 \pm 0.13$ \\
$\mathrm{Cl}^{-}\left(\mathrm{ng} \mathrm{m}^{-3}\right)$ & $15 \pm 11$ & $2.6 \pm 2$ & 7.2 & $2.6 \pm 1.3$ \\
$\mathrm{Na}^{+}\left(\mathrm{ng} \mathrm{m}^{-3}\right)$ & $33 \pm 20$ & $2.8 \pm 1.4$ & 13.6 & $4.1 \pm 1.5$ \\
$\mathrm{Cl}^{-} / \mathrm{Na}^{+}$ & $0.45 \pm 0.3$ & $1.24 \pm 1.2$ & 0.53 & $0.7 \pm 0.4$ \\
$\mathrm{NH}_{4}^{+}\left(\mathrm{ng} \mathrm{m}^{-3}\right)$ & $4.0 \pm 3.8$ & $5.7 \pm 2.4$ & 13.2 & $18 \pm 6$ \\
\hline
\end{tabular}

respective particle formation rates $J_{3-25}$ and the range of the observed particle diameter $D_{\mathrm{p}}$ for these events. In contrast, local contamination provoked strong particle bursts, which typically showed spiky and strongly enhanced particle concentrations $\left(\mathrm{UCP}_{3-25}\right.$ concentrations $>2500 \mathrm{~cm}^{-3}, J_{3-25}$ typically $>10 \mathrm{~s}^{-1}$ ) within a wide particle size range as marked with white frames in Fig. S4.

For the rest of the measuring period in 2015, PNSDs were prima facie monotonous with a mode maximum around $60 \mathrm{~nm}$ (Fig. 8). Notably, an almost persistent Aitken mode around $34 \mathrm{~nm}$ was present, which is also obvious in the mean PNSD derived from DMA 3081 data between doy 28 and doy 33 (Supplement, Fig. S5). In contrast, merely an accumulation mode could be identified in the corresponding mean PNSD covering the period from doy 23 to the end of the campaign in 2016 (Fig. 8). In the first part of the latter campaign (doy 12 through doy 22, measured with the nanoDMA 3085), an additional modal maxima between 10 and $30 \mathrm{~nm}$ sporadically appeared (Fig. S6).

\subsection{Ionic composition of bulk and size-segregated aerosol}

Though super-micrometer particles were not captured by the SMPS data, PNSD appeared clearly governed by submicrometer aerosol (Fig. 8), indicating a crucial role of nss- $\mathrm{SO}_{4}^{2-}$ in the chemical composition of the aerosol. Indeed this was supported by the results from bulk and sizesegregated aerosol samplings. Throughout both campaigns, about $(75 \pm 6) \%$ of the aerosol mass consisted of biogenic sulfur aerosol (nss- $\mathrm{SO}_{4}^{2-}$ and $\mathrm{MS}^{-}$), leaving only about $(9 \pm 5) \%$ for sea salt aerosol, while the highly variable $\mathrm{NH}_{4}^{+}$ portion contributed to about $(6 \pm 4) \%$. The amount of sea salt aerosol was calculated from the measured $\mathrm{Na}^{+}$concentrations referring to standard mean ocean water composition with an $\mathrm{Na}^{+}$/ sea salt mass ratio of 0.306 (Holland, 1993).

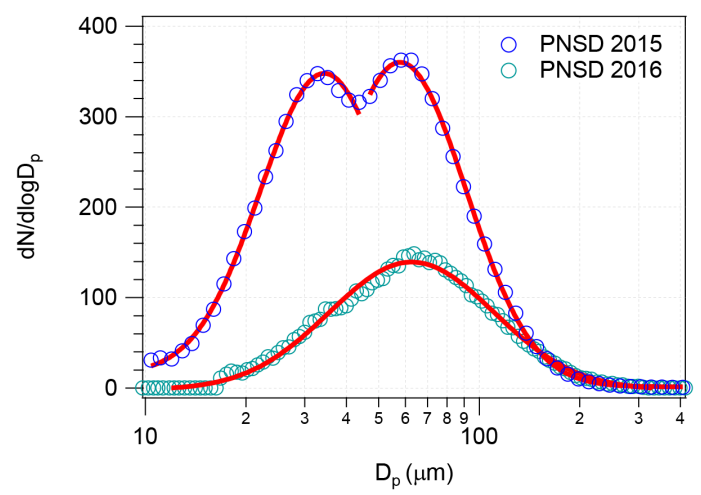

Figure 8. Mean PNSD during clear sky conditions measured with DMA 3081 during the campaign in 2015 (blue circles) and 2016 (turquoise circles). The red lines are lognormal fits with geometric mean diameters of 34 and $58 \mathrm{~nm}$ for the bimodal distribution observed in 2015 and $63 \mathrm{~nm}$ for 2016.

Note that due to analytical problems we assumed an $\mathrm{NO}_{3}^{-}$ portion of $7.4 \%$ in the above mass balance estimate, according to results from three former summer campaigns at Kohnen (Piel et al., 2006). Ion balance considerations revealed that the sampled aerosol was constantly acidic, i.e., $(0.7 \pm 0.3)$ neq $\mathrm{m}^{-3} \mathrm{H}^{+}$, corresponding to $(40 \pm 15) \% \mathrm{H}^{+}$in 2015 and $(0.8 \pm 0.6)$ neq $\mathrm{m}^{-3} \mathrm{H}^{+}$or $(25 \pm 16) \% \mathrm{H}^{+}$equivalent contingent in 2016. Note that these figures are nota bene a lower limit because we ignore here any $\mathrm{HNO}_{3}$ part due to given analytical problems. Although $\mathrm{Cl}^{-} / \mathrm{Na}^{+}$mass ratios were highly variable $(1.0 \pm 0.9$ in 2015 and $0.7 \pm 0.3$ in 2016), a significant $\mathrm{Cl}^{-}$depletion relative to the seawater composition $\left(\mathrm{Cl}^{-} / \mathrm{Na}^{+}=1.8\right)$ was evident, indicating $\mathrm{HCl}$ mobilization by acids like $\mathrm{HNO}_{3}$ or $\mathrm{H}_{2} \mathrm{SO}_{4}$.

Generally ion concentrations (except $\mathrm{NH}_{4}^{+}$) were considerably higher during LPS 15 and LPS16 compared to clear 
Table 3. List of distinct enhanced UCP concentrations and natural nucleation burst events apart from the main NPF (event numbers refer to Fig. 7). The initial nucleation rate (mean \pm SD) is specified together with the period of the $\mathrm{UCP}_{3-25}$ rise and the range of the particle diameter $D_{\mathrm{p}}$.

\begin{tabular}{lllccr}
\hline Event & Event start & Event end & $J_{3-25}\left(\mathrm{~s}^{-1}\right)$ & Period of $\mathrm{UCP}_{3-25}$ rise & $D_{\mathrm{p}}$ range (nm) \\
\hline 1 & 17 Jan, 12:00 & 17 Jan, 15:00 & $0.05 \pm 0.02$ & $12: 00$ to 15:00 & $<3.0$ to 6.0 \\
2 & 18 Jan, 00:00 & 18 Jan, 12:00 & $0.06 \pm 0.02$ & 00:00 to 02:00 & 8.0 to 25 \\
3 & 18 Jan, 13:00 & 18 Jan, 14:00 & $0.15 \pm 0.03$ & $13: 00$ to 14:00 & $<3.0$ to 8.0 \\
4 & 18 Jan, 18:00 & 18 Jan, 24:00 & $0.24 \pm 0.04$ & $18: 00$ to 21:00 & 6.0 to 40 \\
5 & 19 Jan, 17:00 & 19 Jan, 24:00 & $0.11 \pm 0.03$ & $17: 00$ to 19:00 & 8.0 to 12 \\
\hline
\end{tabular}

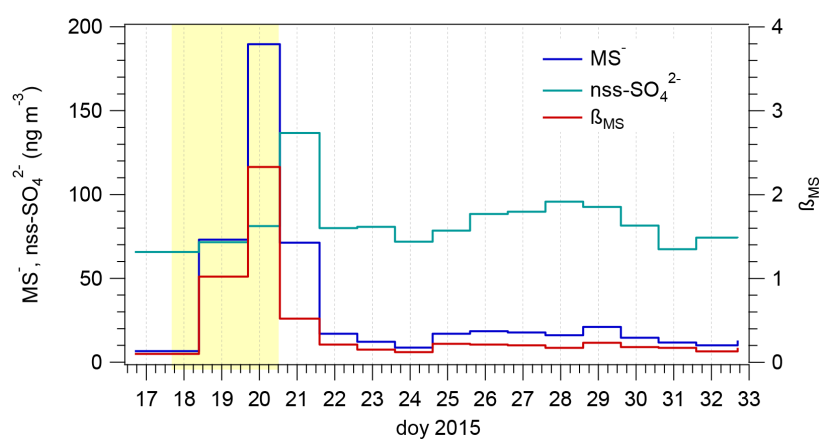

Figure 9. Time series of the measured $\mathrm{MS}^{-}$and nss- $\mathrm{SO}_{4}^{2-}$ concentrations as well as the $\mathrm{MS}^{-} / \mathrm{nss}^{-} \mathrm{SO}_{4}^{2-}$ mass ratio $\beta_{\mathrm{MS}}$ from bulk aerosol (low volume) sampling during the campaign 2015 . The period of LPS15 is shaded in yellow.

sky conditions (Table 2). The time series of nss- $\mathrm{SO}_{4}^{2-}$ and $\mathrm{MS}^{-}$as well as $\beta_{\mathrm{MS}}$ derived from low-volume sampling are shown in Figs. 9 and 10, while the results for $\mathrm{Na}^{+}$ and $\mathrm{NH}_{4}^{+}$are presented in the Supplement, Fig. S7. Striking features were extremely high biogenic sulfur concentrations during LPS15 and shortly after (doy 19 through doy 21 ; Fig. 9) in combination with notable $\mathrm{Na}^{+}$concentrations around $53 \mathrm{ng} \mathrm{m}^{-3}$ (Fig. S7a). Interestingly, $\mathrm{MS}^{-}$concentrations first hit a peak $\left(190 \mathrm{ng} \mathrm{m}^{-3}\right)$ on doy 19-20, while the nss- $\mathrm{SO}_{4}^{2-}$ peak $\left(137 \mathrm{ng} \mathrm{m}^{-3}\right)$ succeeded it with a delay of 1 day. Considering the merely daily resolution of the lowvolume sampling procedure (during this event low-volume sampling started and ended at around 16:00), enhanced biogenic sulfur concentrations seemed to arise in the final stage of LPS15. In addition, $\beta_{\mathrm{MS}}$ was considerably higher compared to the rest of the season $(1.3 \pm 0.9$ versus $0.18 \pm 0.03)$ and throughout the observation period in $2016(0.23 \pm 0.13)$. Thereby $\beta_{\mathrm{MS}}$ during clear sky conditions was intermediate between those encountered in coastal regions (Legrand and Pasteur, 1998) and at Concordia (close to 0.1 from November to April; Legrand et al., 2017a). Concerning LPS16, on the other hand, notable marine aerosol concentrations (biogenic sulfur and $\mathrm{Na}^{+}$; Figs. 10 and S7b) were observed, but now clearly in the aftermath of the stormy period.
Figures 11 and 12 show the size-segregated composition of the aerosol derived from impactor samples taken 2015 and 2016. Note that in case of 2016 we could not assign particular impactor results to LPS16 due to the short duration of this event compared to the sampling period. In Fig. 11, percentage entries denote the portion of the corresponding ion mass in the size range $>1 \mu \mathrm{m}$ (supermicrometer or coarse mode) calculated from the inverted profiles. Generally consistent with comparable measurements conducted at Concordia (Legrand et al., 2017a), a significantly larger part of $\mathrm{MS}^{-}$compared to nss- $\mathrm{SO}_{4}^{2-}$ resided in the coarse mode, resulting in higher $\beta_{\mathrm{MS}}$ ratios there (range: 0.4 up to 2.3 during LPS15 when MSA reached $190 \mathrm{ng} \mathrm{m}^{-3}$; Fig. 13). Concerning sea salt aerosol, nearly half of the $\mathrm{Na}^{+}$ mass was present as sub-micrometer aerosol (Fig. 11). On the whole, ion balance considerations (again inevitably neglecting $\mathrm{HNO}_{3}$ ) indicated acidic sub-micrometer aerosol, while in super-micrometer samples $\mathrm{nss}_{-} \mathrm{SO}_{4}^{2-}$ and $\mathrm{MS}^{-}$ were roughly counterbalanced by $\mathrm{Na}^{+}$and $\mathrm{NH}_{4}^{+}$, which is in agreement with previous results from Concordia during summer (Becagli et al., 2012; Legrand et al., 2017a). However, ion balance results appeared not as clear-cut as found in the bulk low-volume Teflon-nylon filter combination samples: for sub-micrometer aerosol the mean excess anionic portion was merely 0.074 neq $^{-3}$ in 2015 and $0.03 \mathrm{neq} \mathrm{m}^{-3}$ in 2016, while for super-micrometer aerosol we found a mean excess cation part of $0.015 \mathrm{neq} \mathrm{m}^{-3}$ (2015) and 0.084 neq $^{-3}$ (2016). There are two main plausible reasons for this discrepancy: (i) a more pronounced loss of acidic gases from the impactor foils and (ii) an efficient sampling of gaseous $\mathrm{HCl}$ and $\mathrm{HNO}_{3}$ on nylon filters (Piel, 2004; Piel et al., 2006). Again during LPS15, impactor results (covered mainly by the first and partly by the second impactor sampling period) exhibited some conspicuous features: particle mass size distributions (PMSDs) for $\mathrm{MS}^{-}$appeared somewhat broader and a considerably greater part of nss- $\mathrm{SO}_{4}^{2-}$ and $\mathrm{NH}_{4}^{+}$resided in the super-micrometer mode (Fig. 11). Regarding the 2016 campaign, impactor results (Fig. 12) were apparently comparable to the 2015 campaign for prevailing clear sky conditions (covered by impactor samples 3-5; Fig. 11). 


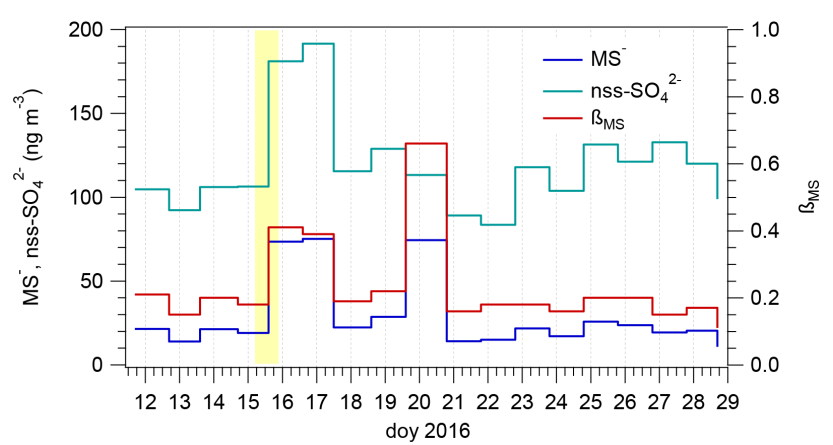

Figure 10. Time series of the measured $\mathrm{MS}^{-}$and nss- $\mathrm{SO}_{4}^{2-}$ concentrations as well as the $\mathrm{MS}^{-} / \mathrm{nss}^{-} \mathrm{SO}_{4}^{2-}$ mass ratio $\beta_{\mathrm{MS}}$ from bulk aerosol (low volume) sampling during the campaign 2016. The period of LPS16 is shaded in yellow.

\section{Discussion}

\subsection{Case study LPS15: cyclone-induced marine air advection and NPF}

\subsubsection{Bulk and size-segregated chemical composition}

In Dronning Maud Land cyclone-driven marine air intrusions are infrequent, sporadic events that are often associated with high precipitation rates (Birnbaum et al., 2006; Schlosser et al., 2010; Welker et al., 2014; Kurita et al., 2016). Such a cyclone-induced advection of marine boundary layer air masses towards the Antarctic Plateau had essentially coined the physical and chemical properties of the aerosol on-site, most noticeably by a maximum of biogenic sulfur concentrations and the occurrence of an NPF event. During a previous similar general weather situation at Kohnen (10 and 11 January 2002; LPS02), Piel et al. (2006) reported even strikingly higher $\mathrm{nss}^{-\mathrm{SO}_{4}^{2-}}\left(1100 \mathrm{ng} \mathrm{m}^{-3}\right)$ and $\mathrm{MS}^{-}$ $\left(350 \mathrm{ng} \mathrm{m}^{-3}\right)$ maxima, though about $48 \mathrm{~h}$ after the passing of the frontal system and the transition from marine to continental air mass origin. In contrast to the LPS15, LPS02 came along with heavy snowfall (Birnbaum et al., 2006). Another peculiarity of our recent observations was a preceding and well-defined $\mathrm{MS}^{-}$peak pursued by a distinct nss- $\mathrm{SO}_{4}^{2-}$ maximum (Fig. 9) compared to their simultaneous emergence in the aftermath of LPS02 described in Piel et al. (2006). Given that $\mathrm{MS}^{-}$should have been primarily formed by heterogeneous liquid-phase chemistry prevalent in the marine boundary layer (Legrand et al., 2001; Bardouki et al., 2002; Hoffmann et al., 2016), the segregated $\mathrm{MS}^{-}$peak indicated a temporary and efficient advection of such air masses. In addition, a striking peak of the sea salt tracer $\mathrm{Na}^{+}$appeared along with the $\mathrm{MS}^{-}$maximum (Supplement, Fig. S7), emphasizing the impact of marine boundary layer air masses during this part of LPS15. Note that $\mathrm{Na}^{+}$remained at typical mean concentrations around $7 \mathrm{ng} \mathrm{m}^{-3}$ during the former biogenic sulfur maximum between 14 and 15 January 2002 (Piel, 2004).
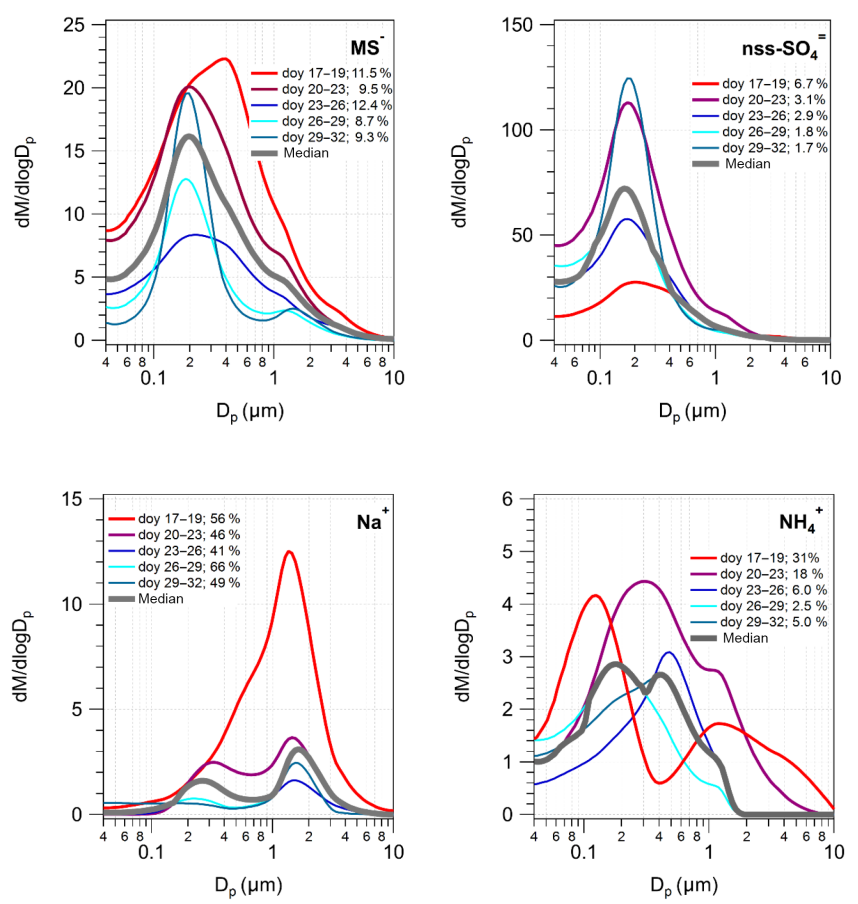

Figure 11. Results from size-segregated (Berner impactor) sampling during the campaign 2015. Bold reddish lines are the mass size distributions during LPS15. Percentage entries in the legend denote the portion of the corresponding ion mass in the size range $>1 \mu \mathrm{m}$ (super-micrometer or coarse mode) calculated from the inverted profiles. The bold gray line is the median mass size distribution of the corresponding ion.

The 5-day back trajectories confirmed these conclusions (Fig. 14; starting point $100 \mathrm{~m}$ above Kohnen): air masses during LPS15 were generally marine 2 to 3 days before arrival at Kohnen. Trajectories representing doy 19 (NPF event; reddish and yellow traces in Fig. 14a) spent several hours within the marine boundary layer close to the East Antarctic coast before arrival at Kohnen, largely following the contour lines of the local topography. All trajectories started under cyclonic curvature, finally approaching Kohnen in an anticyclonic bow from northerly directions (Fig. 14). In order to estimate the reliability of this trajectory-based finding, we repeated the calculations with an initial height of $10 \mathrm{~m}$ above Kohnen, calculated trajectory ensembles, and made an extra attempt using the isentropic approach instead of the 3-D wind field from GDAS data (Figs. S8-S10). Though appreciable differences regarding the geographic location of the corresponding source regions and trajectory course were obvious, in the end the basic aforementioned implications appeared consistent. In contrast to this finding, air masses originated and stayed within continental Antarctica during the biogenic sulfur peaks observed during 14 and 15 January 2002 (Piel et al., 2006), which could be confirmed by a reanalysis with HYSPLIT trajectories based on NCEP meteorological data (Fig. S11). Similar air mass trajectories (not shown) were ob- 

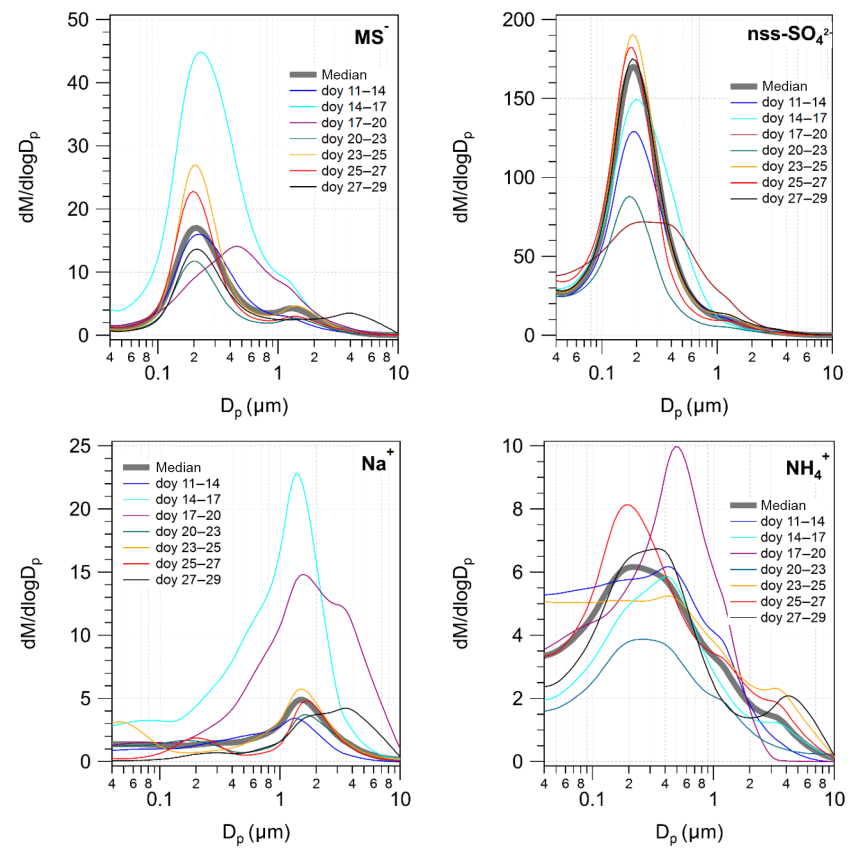

Figure 12. Results from size-segregated (Berner impactor) sampling during the campaign 2016 with the following mass portion of the respective ions in the super-micrometer range (>1 $\mu \mathrm{m})$ : $\mathrm{MS}^{-}$ $14 \%$ (a), nss- $\mathrm{SO}_{4}^{2-} 3 \%$ (b), $\mathrm{Na}^{+} 46 \%$ (c), and $\mathrm{NH}_{4}^{+} 15 \%$ (d). The bold gray line is the median mass size distribution of the corresponding ion.

served during and in the aftermath of a short stormy period LPS16, which was again characterized by enhanced $\mathrm{Na}^{+}$and biogenic sulfur loadings (Figs. 10 and S7b).

Regarding the chemical composition of the aerosol during the final stage of LPS15, subsequent increasing nss- $\mathrm{SO}_{4}^{2-}$ along with declining $\mathrm{MS}^{-}$concentrations indicated a minor importance of liquid-phase chemistry (Hoffmann et al., 2016). We may speculate that intrusions of marine boundary layer into the so-called buffer layer were responsible for the efficient advection of gaseous DMS photooxidation products like $\mathrm{SO}_{2}$ and DMSO (Davis et al., 1998; Russel et al., 1998). Russel et al. (1998) assumed that the buffer layer typically extends from the turbulent marine boundary layer (400 to $700 \mathrm{~m}$ ) up to a capping inversion (1400 to $1900 \mathrm{~m}$ ). While transported to continental Antarctica, gas-phase photooxidation processes should have dominated, leading finally to a preferred formation of $\mathrm{H}_{2} \mathrm{SO}_{4}$ at the expense of MSA (Preunkert et al., 2008). This plausible but subtle transport route could not be unequivocally deduced from respective backward trajectory analyses because in the case at hand the presence and the extent of a buffer layer could not be ascertained from available meteorological data.

Another conspicuous point was the comparatively large part of $\mathrm{MS}^{-}$, most notably $\mathrm{NH}_{4}^{+}$, found in coarse-mode aerosol during LPS15 (11.5 and 39\%, respectively; Fig. 11). Apart from post-sampling reactions on the first two im-

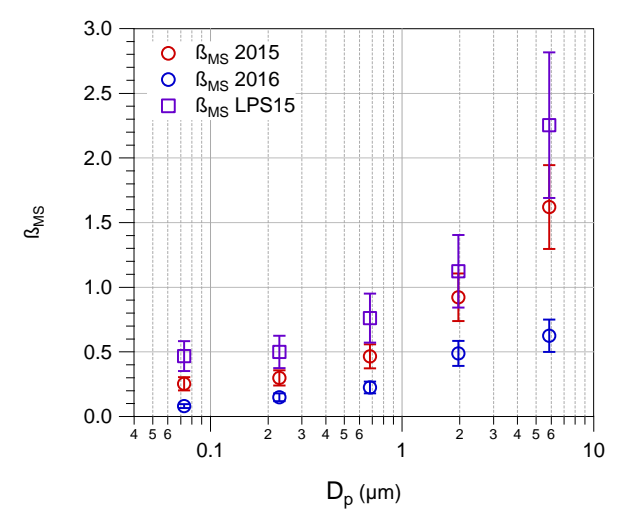

Figure 13. Mean size-segregated results for the $\mathrm{MS}^{-} / \mathrm{nss}_{-} \mathrm{SO}_{4}^{2-}$ mass ratio $\beta_{\mathrm{MS}}$ determined for each of the five impactor stages for both seasons and for the event LPS15.

pactor stages, which could not be entirely excluded, preceding heterogeneous processes in the atmosphere, i.e., the acidification of sea salt particle surfaces and subsequent chemisorption of (basic) $\mathrm{NH}_{3}$, should be a more realistic explanation. Though $\mathrm{MS}^{-}$added up to merely 0.03 compared to $0.072 \mathrm{nmol} \mathrm{m}^{-3} \mathrm{NH}_{4}^{+}$in coarse aerosol during LPS15, other acidic gases (probably $\mathrm{HNO}_{3}$, but according to our data only to a minor extent $\mathrm{H}_{2} \mathrm{SO}_{4}$ ) reacted with coarsemode sea salt particles and scavenged gaseous $\mathrm{NH}_{3}$. Previous size-segregated aerosol sampling at Concordia revealed that coarse-mode ammonium was primarily present as sulfate or methane sulfonate salts, while nitrate was of minor importance (Becagli et al., 2012). During the Japanese-Swedish joint Antarctic expedition (JASE), on the other hand, Hara et al. (2014) reported $\mathrm{H}_{2} \mathrm{SO}_{4}$ - and MSA-modified sea salt particles close to the coast, while farther inland most probably the reaction with $\mathrm{HNO}_{3}$ dominated. According to recent year-round investigations at Concordia, however, it appears that the competing role of $\mathrm{HNO}_{3}$ vs. acidic sulfur aerosol is more complicated: regarding coarse-mode sea salt particles, only during midsummer and late summer does sulfuric aerosol and not $\mathrm{HNO}_{3}$ become the preferred acidic reactant (Legrand et al., 2017b).

In conclusion it is worthwhile to consider the results from Neumayer. This coastal site was governed by the same lowpressure system (LPS15) provoking a blizzard there around 19 January 2015. From there, daily low-volume sampling (Teflon-nylon filter combination), CP concentration (measured with a CPC $3022 \mathrm{~A}$, TSI; $\left.D_{\mathrm{p}(50 \%)}=7 \mathrm{~nm}\right)$, and meteorological data were available. Again, biogenic sulfur (particularly $\left.\mathrm{MS}^{-}\right), \mathrm{Na}^{+}$, and $\mathrm{CP}$ concentrations showed distinctive maxima though about 1 day after the LPS15 (Fig. S12), similar to the previous situation described by Piel et al. (2006). Consequently we can assume that this characteristic weather situation transported marine aerosol throughout DML. But in contrast to Kohnen the impact of LPS15 on the delayed particle concentration and ionic composition maxima at Neu- 

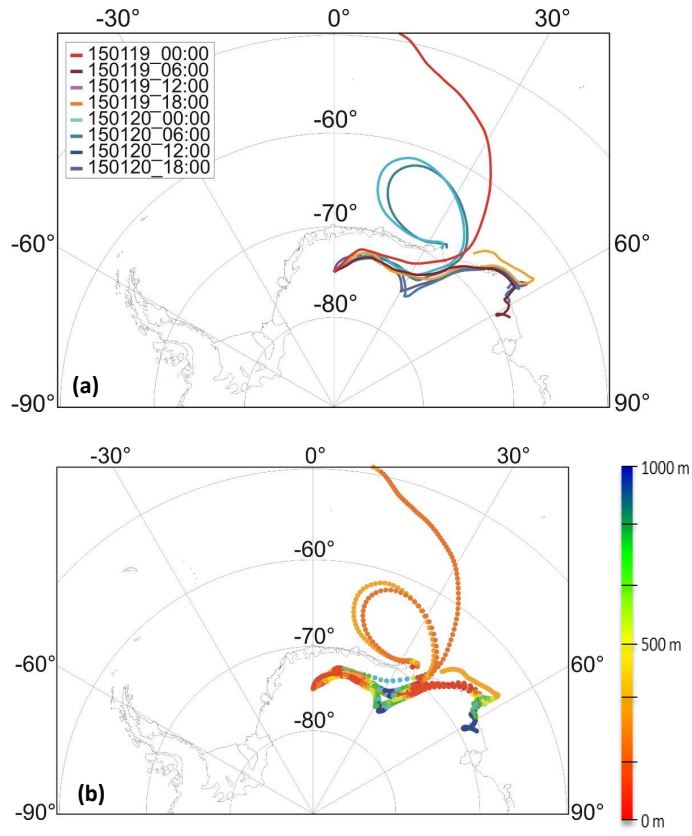

Figure 14. The 5-day backward trajectories during the NPF event calculated with a trajectory starting height of $100 \mathrm{~m}$ above Kohnen at the points in time given in the legend (a). Below, the travel height above the ground (local topography) is illustrated in a color-coded scale (point interval $1 \mathrm{~h})(\mathbf{b})$.

mayer was less pronounced. Pant et al. (2010) concluded from previous particle concentration and size distribution data measured at coastal Maitri that during the impact of cyclones, coarse-mode sea salt aerosol increased by an order of magnitude compared to calm weather conditions, which is similar to our results during LPS15 (Table 2).

\subsubsection{NPF, particle growth, and size-segregated chemical composition}

Obviously the most striking feature during LPS15 was a distinctive NPF event. The closed shape of PNSD, starting with a modal maximum not less than $12 \mathrm{~nm}$, implied that the actual particle nucleation event should have occurred upwind of Kohnen. Assuming a constant growth rate of $0.6 \mathrm{~nm}$ $\mathrm{h}^{-1}$ throughout advection to the measuring site, particle nucleation thus happened about $20 \mathrm{~h}$ before, i.e., according to backward trajectories roughly $700 \mathrm{~km}$ away from Kohnen at $73^{\circ} \mathrm{S}, 19^{\circ} \mathrm{E}$ and $160 \mathrm{~m}$ above the ground (all virtually independent from the choice of the starting height). Note that the observed particle growth was confined to the nucleation mode and consequently did not reach a size range potentially relevant for acting as CCN. As described in Weller et al. (2015), NPF events at Neumayer generally showed almost comparable growth rates. Therein we used a simple estimate based on Nieminen et al. (2010) and Yli-Juuti et al. (2011) that demonstrated the need for condensable va- pors other than sulfuric acid to sustain the observed particle growth (Weller et al., 2015). We employed the same approach in connection with the NPF event at Kohnen (i.e., Eq. 3 in Weller et al., 2015, using $T=250 \mathrm{~K}$ ), resulting in $1.4 \times 10^{7}$ molec $\mathrm{cm}^{-3}$ gaseous $\mathrm{H}_{2} \mathrm{SO}_{4}$ necessary for the determined growth rate of $0.6 \mathrm{~nm} \mathrm{~h}^{-1}$. Again, this appeared at least an order of magnitude too high compared to the respective values published (e.g., Mauldin III et al., 2004), emphasizing the importance of other yet unknown condensable vapors, most probably low-volatility organic compounds (Metzger et al., 2010; Tröstl et al., 2016). Interestingly, Kyrö et al. (2013) identified biogenic emissions by nearby melting ponds as a potential source for condensable vapor. The surroundings of Kohnen, however, are completely ice covered throughout as typical for the Antarctic Plateau region. The nearest rocky outcrops are more than $200 \mathrm{~km}$ away.

In this context it is interesting to compare our results with previous PNSD measurements conducted at the South Pole during two summer campaigns (Park et al., 2004) and year-round observations at Concordia (Järvinen et al., 2013). Results from the South Pole showed similar PNSDs with mean a $D_{\mathrm{p}}$ between 60 and $98 \mathrm{~nm}$ (Park et al., 2004, Table 4 therein), while PNSDs at Concordia were appreciably lower with $D_{\mathrm{p}}=39 \mathrm{~nm}$ (Järvinen et al., 2013). Järvinen et al. (2013) could detect NPF throughout the year under condensation sink values of around $1.8 \times 10^{-4} \mathrm{~s}^{-1}$, comparable to the condensation sink range found at Kohnen. At Concordia, NPF events with a determinable growth rate were not connected with low-pressure systems but essentially observed under air mass advection from the upper atmosphere (Järvinen et al., 2013). This fact indicates that also at Kohnen, NPF may potentially occur during clear sky conditions, but could not be detected within our admittedly limited observation period. Furthermore, the growth rates determined so far at coastal sites (Virkkula et al., 2007; Asmi et al., 2010; Kyrö et al., 2013; Weller et al., 2015) appeared comparable to GR reported from continental Antarctica (Järvinen et al., 2013; Chen et al., 2017) and were within a similar broad range between 0.2 and up to $8.8 \mathrm{~nm} \mathrm{~h}^{-1}$.

Pant et al. (2010) presented a detailed analysis about the impact of passing cyclones on particle size distributions at coastal Maitri. The authors observed bimodal PNSD with a coarse-mode maxima around $2 \mu \mathrm{m}$ and a broad Aitken mode between 0.04 and $0.1 \mu \mathrm{m}$ when a storm approached the site. Occasionally NPF occurred just after the passage of a cyclone associated with particle growth rates between 0.2 and $0.6 \mathrm{~nm} \mathrm{~h}^{-1}$. From meteorological data the authors conclude that the observed NPF events were linked with the mixing of marine and continental air during the subsidence of free tropospheric air after the storm (Pant et al., 2010). 


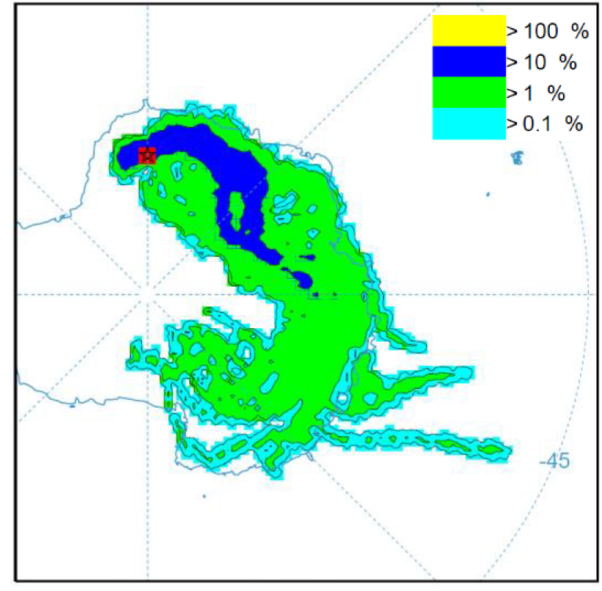

Figure 15. Daily 10-day backward trajectories (3-D approach, starting height $100 \mathrm{~m}$ ) during clear sky conditions in 2016 (doy 12 to doy $31, N=80$ ). Shown is the relative (percentage) number of trajectory intersections on a given grid cell (resolution $1^{\circ} \times 1^{\circ}$ ).

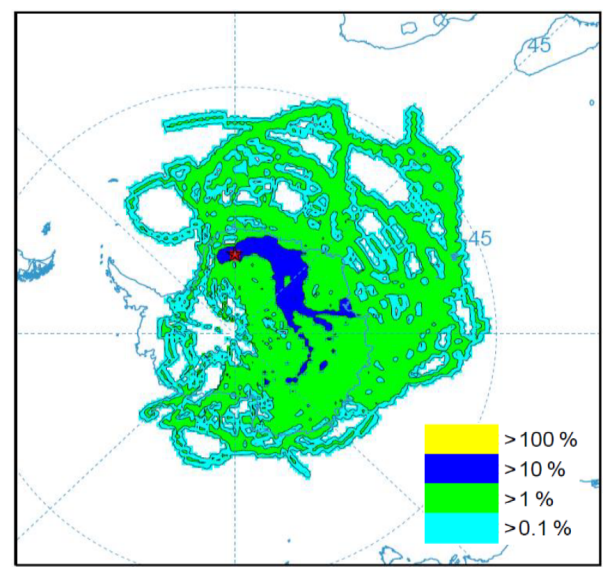

Figure 16. Daily 20-day backward trajectories (3-D approach, starting height $100 \mathrm{~m}$ ) during clear sky conditions in 2016 (doy 12 to doy $31, N=80$ ). Shown is the relative (percentage) number of trajectory intersections on a given grid cell (resolution $1^{\circ} \times 1^{\circ}$ ).

\subsection{The standard case: clear sky conditions and aged aerosol}

On the one hand, LPS15 was attended with an expeditious advection of marine boundary layer air, leading to an enhanced entry of marine aerosol and secondary aerosol precursors, highly variable PNSD, and an NPF event. On the other hand, clear sky conditions largely prevailed during our recent campaign, but also during previous summer campaigns (Piel et al., 2006). The present observations at Kohnen showed that throughout this characteristic synoptic situation, appreciably lower particle number concentrations restricted within the accumulation mode were typical. Concerning the ionic composition, $\mathrm{MS}^{-}$and $\mathrm{Na}^{+}$concentrations were considerably lower compared to their maxima accompanied with the impact of LPS15 (Figs. 9 and S7a) in contrast to virtually constant, though highly variable mean $\mathrm{NH}_{4}^{+}$concentrations $\left(5.2 \pm 2.6 \mathrm{ng} \mathrm{m}^{-3}\right.$ in 2015 and $17.9 \pm 6 \mathrm{ng} \mathrm{m}^{-3}$ in 2016). We have no explanation at hand for the approximately threefold higher mean $\mathrm{NH}_{4}^{+}$concentrations in 2016, but the results presented in Piel et al. (2006) also showed large annual fluctuations. We finally calculated a mass ratio of $\mathrm{NH}_{4}^{+}$to nss$\mathrm{SO}_{4}$ of 0.06 for 2015 and 0.15 for 2016. At least the former value was in the range of what was concurrently observed at Neumayer in January 2015. Most probably, atmospheric $\mathrm{NH}_{3} / \mathrm{NH}_{4}^{+}$ratios were correspondingly variable depending on the availability of acidic trace gases (note that $\mathrm{NH}_{3}$ could not be captured by the sampling methods used).

Turning towards biogenic sulfur aerosol, $\beta_{\mathrm{MS}}$ ratios decreased to values around 0.2 under clear sky conditions, as is typical for continental Antarctica (Piel et al., 2006; Weller and Wagenbach, 2007; Preunkert et al., 2008; Becagli et al., 2012), while during LPS15, $\beta_{\mathrm{MS}}$ was more comparable to coastal sites like Neumayer and Dumont D'Urville (Legrand and Pasteur, 1998).

The air mass history during clear sky conditions was assessed by composite backward trajectory calculations and is summarized in Fig. 15. Even 10 days before arrival at Kohnen with a characteristic anticyclonic curvature, trajectory origins remained principally inside the Antarctic continent and thus remote from marine source regions. Varying initial start height did not essentially change this general feature, but employing the isentropic instead of the 3-D approach showed an increased relevance of marine source regions (see Fig. S13). Upon extending the trajectory travel time to 20 days, the origin of the air masses eventually became marine (Fig. 16), covering a large part of the Southern Ocean, except the western part of the Weddell Sea and the Bellingshausen Sea. The relevance of air mass transport via the free troposphere was difficult to assess, mainly due to the generally highly variable and poorly characterized depth of the marine boundary layer and especially the vertical extent of the atmospheric boundary layer over Antarctica. According to Russell et al. (1998), the border between the marine boundary layer and the free troposphere typically varies between 1400 and $1900 \mathrm{~m}$, while on the Antarctic Plateau only a shallow atmospheric boundary layer of no more than a few hundred meters is typical (Van As et al., 2006). Inspection of the calculated trajectories revealed that they typically originated within the marine boundary layer (i.e., mainly below $1500 \mathrm{~m}$ ) and essentially stayed below $500 \mathrm{~m}$ above the ground across continental Antarctica.

Surprisingly, while the amount of sea salt aerosol was highly variable, the super-micrometer-mode fraction of sea salt aerosol remained constant at around 50\% during rapid and efficient marine boundary layer air mass advection under LPS15 and during long-range transport under clear sky conditions (Figs. 11 and 12). Since our sea salt mass size distribution also appeared similar to that typically observed at Concordia (Jourdain et al., 2008; Legrand et al., 2017b), 
we infer that the transport of coarse-mode sea salt particles to continental Antarctica was generally inefficient, regardless of the general weather situation and transport time. Finally, the fact that observed $\beta_{\mathrm{MS}}$ ratios were in general higher in the coarse mode (supported by measurements in coastal Antarctica by Teinilä et al., 2000, and Rankin and Wolff, 2003) implied a preferential loss of $\mathrm{MS}^{-}$during transport towards the Antarctic Plateau region. In contrast, recent results from Concordia give strong evidence for a preferential photochemical depletion of MSA in the atmosphere above the plateau during austral summer (Legrand et al., 2017a) but less indication for fractional loss en route. Nevertheless, both processes of fractionation and photochemistry could be potential explanations for typically lower $\beta_{\mathrm{MS}}$ ratios commonly found in continental Antarctica compared to the coastal regions (Piel et al., 2006; Weller and Wagenbach, 2007; Preunkert et al., 2008).

\section{Conclusions}

We measured aerosol size distributions and conducted bulk and size-segregated aerosol sampling during two summer campaigns at the continental Antarctic station Kohnen. This extended approach allowed for a detailed synopsis of the physical and chemical properties of summer aerosol in this region. For the first time, the impact of passing cyclones on aerosol advection into the Antarctic Plateau region was examined. Based on these admittedly still limited investigations, we may conclude that during austral summer, the transport of marine aerosol to Kohnen in particular and to continental DML in general was mediated by two different synoptic situations: (i) the impact of low-pressure systems in the western part of the South Atlantic associated with temporarily exceptional marine aerosol concentrations and (ii) persistent long-range transport providing a background aerosol level during clear sky conditions over DML. In the present study, a distinct low-pressure event (LPS15) was additionally associated with NPF. Under prevailing clear sky conditions, on the other hand, aged aerosol and less aerosol (by mass and number concentration) entered DML in air masses that were typically continental for about 10 days before. We tentatively infer that our recent observation, i.e., NPF and peaking marine aerosol concentrations during LPS15, could be of fortuitous occurrence since unexpectedly just the trace compounds seemed to hardly be depleted by precipitation. In contrast, during the mentioned blizzard in 2002 (LPS02) reported by Piel et al. (2006), biogenic sulfur concentrations stayed first quite low but peaked at about $48 \mathrm{~h}$ in the aftermath of the storm. Though we refer to two recent and three previous studies, just three LPS and one pronounced NPF event occurred that could be analyzed in detail, emphasizing their sporadic nature. Hence, a worthwhile confirmation of our conclusions would clearly require similar investigations at this site. Such effort is important to better understand the role of biogenic aerosol in general and in particular the impact of NPF events on regional climate forcing.

Though the efficient transport of biogenic sulfur (and also sea salt) aerosol to continental DML may be associated with cyclonic activity in the South Atlantic, in the long run the crucial transport pathway of marine aerosol during austral summer should be long-range transport under typical clear sky conditions. In particular for biogenic sulfur, showing a pronounced summer maximum (Weller and Wagenbach, 2007), we suppose that transport to DML, deposition, and final storage in firn and glacial ice will be dominated by prevailing clear sky conditions. Thus dry deposition, but to an only minor extent wet deposition (partly associated with clear sky precipitation), would be decisive. Consequently future research activities should also envisage assessing dry deposition velocities at this site, e.g., by gradient and/or eddy correlation studies (Grönlund et al., 2002; Contini et al., 2010). On the other hand, retrieving meaningful historic aerosol concentrations from ice core archives also needs a thorough consideration of snow accumulation since snow accumulation co-determines trace compound concentrations in firn and ice (Fischer et al., 1998), which is evidently governed by the infrequent impact of low-pressure systems (Birnbaum et al., 2006; Schlosser et al., 2010; Welker et al., 2014; Kurita et al., 2016). Finally, trajectory analyses indicated that a large part of the Southern Ocean should be considered as a potential source region representative of aerosol deposition in continental DML in contrast to coastal Neumayer where the dominance of the South Atlantic was evident (Minikin et al., 1998).

Data availability. Data from both campaigns reported here are available at https://doi.org/10.1594/PANGAEA.882375 (Weller et al., 2017) for scientific purposes. In this case, we expect collaboration with Rolf Weller (contact: rolf.weller@awi.de).

Supplement. The supplement related to this article is available online at: https://doi.org/10.5194/acp-18-2413-2018-supplement.

Competing interests. The authors declare that they have no conflict of interest.

Acknowledgements. The authors would especially like to thank all technicians present at Kohnen Station, namely Holger Schubert, Torsten Langenkämper, and last but not least, Jens Köhler, whose outstanding engagement actually enabled both air chemistry campaigns at this site. We are thankful to the NOAA Air Resources Laboratory for having made available the HYSPLIT trajectory calculation program and all the input data files used. We thank Kevin Manning for providing us with weather charts based on the Antarctic Mesoscale Prediction System (AMPS). Finally, we appreciate the two anonymous reviewers for their helpful 
comments.

The article processing charges for this open-access publication were covered by a Research

Centre of the Helmholtz Association.

Edited by: Yves Balkanski

Reviewed by: two anonymous referees

\section{References}

Abram, N. J., Mulvaney, R., Wolff, E. W., and Mudelsee, M.: Ice core records as sea ice proxies: An evaluation from the Weddell Sea region of Antarctica, J. Geophys. Res., 112, D15101, https://doi.org/10.1029/2006JD008139, 2013.

Arimoto, R., Hogan, A., Grube, P., Davis, D., Webb, J., Schloesslin, C., Sage, S., and Raccah, F.: Major ions and radionuclides in aerosol particles from the South Pole during ISCAT-2000, Atmos. Environ., 38, 5473-5484, 2004.

Asmi, E., Frey, A., Virkkula, A., Ehn, M., Manninen, H. E., Timonen, H., Tolonen-Kivimäki, O., Aurela, M., Hillamo, R., and Kulmala, M.: Hygroscopicity and chemical composition of Antarctic sub-micrometre aerosol particles and observations of new particle formation, Atmos. Chem. Phys., 10, 4253-4271, https://doi.org/10.5194/acp-10-4253-2010, 2010.

Bardouki, H., Barcellos da Rosa, M., Mihalopoulos, N., Palm, W.U., and Zetsch, C.: Kinetics and mechanism of the oxidation of dimethylsulfoxide (DMSO) and methanesulfinate $\left(\mathrm{MSI}^{-}\right)$by $\mathrm{OH}$ radicals in aqueous medium, Atmos. Environ., 36, 46274634, https://doi.org/10.1016/S1352-2310(02)00460-0, 2002.

Becagli, S., Scarchilli, C., Traversi, R., Dayan, U., Severi, M., Frosini, D., Vitale, V., Mazzola, M., Lupi, A., Nava, S., and Udisti, R.: Study of present-day sources and transport processes affecting oxidized sulphur compounds in the atmospheric aerosol at Concordia (Antarctica) from yearround sampling campaigns, Atmos. Environ., 52, 98-108, https://doi.org/10.1016/j.atmosenv.2011.07.053, 2012.

Birnbaum, G., Brauner, R., and Ries, H.: Synoptic situations causing high precipitation rates on the Antarctic plateau: observations from Kohnen Station, Dronning Maud Land, Antarct. Sci., 18, 279-288, https://doi.org/10.1017/S0954102006000320, 2006.

Bodas-Salcedo, A., Williams, K. D., Ringer, M. A., Beau, I., Cole, J. N. S., Dufresne, J.-L., Koshiro, T., Stevens, B., Wang, Z., and Yokohata, T.: Origins of the Solar Radiation Biases over the Southern Ocean in CFMIP2 Models, J. Climate, 27, 41-56, https://doi.org/10.1175/JCLI-D-13-00169.1, 2014.

Boucher, O., Randall, D., Artaxo, P., Bretherton, C., Feingold, G., Forster, P., Kerminen, V.-M., Kondo, Y., Liao, H., Lohmann, U., Rasch, P., Satheesh, S. K., Sherwood, S., Stevens B., and Zhang, X. Y.: Clouds and Aerosols, in: Climate Change 2013: The Physical Science Basis. Contribution of Working Group I to the Fifth Assessment Report of the Intergovernmental Panel on Climate Change, edited by: Stocker, T. F., Qin, D., Plattner, G.-K., Tignor, M., Allen, S. K., Boschung, J., Nauels, A., Xia, Y., Bex, V., and Midgley, P. M., Cambridge University Press, Cambridge, UK and New York, NY, USA, 2013.

Carslaw, K. S., Lee, L. A., Reddington, C. L., Pringle, K. J., Rap, A., Forster, P. M., Mann, G. W., Spracklen, D. V., Woodhouse,
M. T., Regayre, L. A., and Pierce, J. R.: Large contribution of natural aerosol to uncertainty in indirect forcing, Nature, 503, 67-71, https://doi.org/10.1038/nature12674, 2013.

Chen, X., Virkkula, A., Kerminen, V.-M., Manninen, H. E., Busetto, M., Lanconelli, C., Lupi, A., Vitale, V., Del Guasta, M., Grigioni, P., Väänänen, R., Duplissy, E.-M., Petäjä, T., and Kulmala, M.: Features in air ions measured by an air ion spectrometer (AIS) at Dome C, Atmos. Chem. Phys., 17, 13783-13800, https://doi.org/10.5194/acp-17-13783-2017, 2017.

Contini, D., Donateo, A., Belosi, F., Grasso, F. M., Santachiara, G., and Prodi, F.: Deposition velocity of ultrafine particles measured with the Eddy-Correlation Method over the Nansen Ice Sheet (Antarctica), J. Geophys. Res., 115, D16202, https://doi.org/10.1029/2009JD013600, 2010.

Dal Maso, M., Kulmala, M., Riipinen, I., Wagner, R., Hussein, T., Aalto, P. P., and Lehtinen, E. J.: Formation and growth of fresh atmospheric aerosols: eight years of aerosol size distribution data from SMEAR II, Hyytiälä, Finland, Boreal Environ. Res., 10, 323-336, 2005.

Davis, D., Chen, G., Kasibhatla, P., Jefferson, A., Tanner, D., Eisele, F., Lenschow, D., Neff, W., and Berresheim, H.: DMS oxidation in the Antarctic marine boundary layer: Comparison of model simulations and field observations of DMS, DMSO, $\mathrm{DMSO}_{2}$, $\mathrm{H}_{2} \mathrm{SO}_{4}(\mathrm{~g})$, MSA(g), and MSA(p), J. Geophys. Res., 103, 1657$1678,1998$.

Fischer, H., Wagenbach, D., and Kipfstuhl, J.: Sulfate and nitrate firn concentrations on the Greenland ice sheet 1. Large-scale geographical deposition changes, J. Geophys. Res., 103, 2192721934, 1998.

Fischer, H., Traufetter, F., Oerter, H., Weller, R., and Miller, H.: Prevalence of the Antarctic Circumpolar Wave over the last two millenia recorded in Dronning Maud Land ice, Geophys. Res. Lett., 31, L08202, https://doi.org/10.1029/2003GL019186, 2004.

Fundel, F., Fischer, H., Weller, R., Traufetter, F., Oerter, H., and Miller, H.: Influence of large-scale teleconnection patterns on methane sulfonate ice core records in Dronning Maud Land, J. Geophys. Res., 111, D04103, https://doi.org/10.1029/2005JD005872, 2006.

Gras, J. L. and Keywood, M.: Cloud condensation nuclei over the Southern Ocean: wind dependence and seasonal cycles, Atmos. Chem. Phys., 17, 4419-4432, https://doi.org/10.5194/acp17-4419-2017, 2017.

Grönlund, A., Nilsson, D., Koponen, I. K., Virkkula, A., and Hansson, M. E.: Aerosol dry deposition measured with eddycovariance technique at Wasa and Aboa, Dronning Maud Land, Antarctica, Ann. Glaciol., 35, 355-361, 2002.

Hara, K., Nakazawa, F., Fujita, S., Fukui, K., Enomoto, H., and Sugiyama, S.: Horizontal distributions of aerosol constituents and their mixing states in Antarctica during the JASE traverse, Atmos. Chem. Phys., 14, 10211-10230, https://doi.org/10.5194/acp-14-10211-2014, 2014.

Harris, J. M., Draxler, R. R., and Oltmans, S. J.: Trajectory model sensitivity to differences in input data and vertical transport method, J. Geophys. Res., 110, D14109, https://doi.org/10.1029/2004JD005750, 2005.

Hoffmann, E. H., Tilgner, A., Schrödner, R., Bräuer, P., Wolke, R., and Herrmann, H.: An advanced modeling study on the impacts and atmospheric implications of multiphase dimethyl sul- 
fide chemistry, P. Natl. Acad. Sci. USA, 113, 11776-11781, https://doi.org/10.1073/pnas.1606320113, 2016.

Hogan, A. W. and Barnard, S. C.: Seasonal and frontal variation in the Antarctic aerosol concentration, J. Appl. Meteorol., 17, 1458-1465, 1978.

Holland, H. D.: The Chemistry of Atmosphere and Oceans, 1st Edn., John Wiley \& Sons, New York, 154-157, 1993.

Humphries, R. S., Klekociuk, A. R., Schofield, R., Keywood, M., Ward, J., and Wilson, S. R.: Unexpectedly high ultrafine aerosol concentrations above East Antarctic sea ice, Atmos. Chem. Phys., 16, 2185-2206, https://doi.org/10.5194/acp16-2185-2016, 2016.

Ito, T. and Iwai, K.: On the sudden increase in the concentration of Aitken particles in the Antarctic atmosphere, J. Meteorol. Soc. Jpn., 59, 262-271, 1981.

Järvinen, E., Virkkula, A., Nieminen, T., Aalto, P. P., Asmi, E., Lanconelli, C., Busetto, M., Lupi, A., Schioppo, R., Vitale, V., Mazzola, M., Petäjä, T., Kerminen, V.-M., and Kulmala, M.: Seasonal cycle and modal structure of particle number size distribution at Dome C, Antarctica, Atmos. Chem. Phys., 13, 7473-7487, https://doi.org/10.5194/acp-13-7473-2013, 2013.

Jourdain, B., Preunkert, S., Cerri, O., Castebrunet, H., Udisti, R., and Legrand, M.: Year-round record of sizesegregated aerosol composition in central Antarctica (Concordia station): Implications for the degree of fractionation of sea-salt particles, J. Geophys. Res., 113, D14308, https://doi.org/10.1029/2007JD009584, 2008.

Kaufmann, P., Fundel, F., Fischer, H., Bigler, M., Ruth, U., Udisti, R., Hansson, M., de Angelis, M., Barbante, C., Wolff, E. W., Hutterli, M., and Wagenbach, D.: Ammonium and non-sea-salt sulfate in the EPICA ice cores as indicator of biological activity in the Southern Ocean, Quaternary Sci. Rev., 29, 313-323, https://doi.org/10.1016/j.quascirev.2009.11.009, 2009.

Korhonen, H., Carslaw, K. S., Spracklen, D. V., Mann, G. W., and Woodhouse, M. T.: Influence of oceanic dimethyl sulfide emissions on cloud condensation nuclei concentrations and seasonality over the remote Southern Hemisphere oceans: A global model study, J. Geophys. Res., 113, D15204, https://doi.org/10.1029/2007JD009718, 2008.

Kulmala, M., Dal Maso, M., Mäkelä, J. M., Pirjola, L., Väkevä, M., Aalto, P., Miikkulainen, P., Hämeri, K., and O'Dowd, C. D.: On the formation, growth and composition of nucleation mode particles, Tellus B, 53, 479-490, 2001.

Kurita, N., Hirasawa, N., Koga, S., Matsushita, J., Steen-Larsen, H. C., Masson-Delmotte, V., and Fujiyoshi, Y: Influence of largescale atmospheric circulation on marine air intrusion toward the East Antarctic coast, Geophys. Res. Lett., 43, 9298-9305, https://doi.org/10.1002/2016GL070246, 2016.

Kyrö, E.-M., Kerminen, V.-M., Virkkula, A., Dal Maso, M., Parshintsev, J., Ruíz-Jimenez, J., Forsström, L., Manninen, H. E., Riekkola, M.-L., Heinonen, P., and Kulmala, M.: Antarctic new particle formation from continental biogenic precursors, Atmos. Chem. Phys., 13, 3527-3546, https://doi.org/10.5194/acp13-3527-2013, 2013.

Legrand, M. and Mayewski, P.: Glaciochemistry of polar ice cores: a review, Rev. Geophys., 35, 219-243, 1997.

Legrand, M. and Pasteur, E. C.: Methane sulfonic acid to non-sea salt sulfate ratio in coastal Antarctic aerosol and surface snow, J. Geophys. Res., 103, 10991-11006, 1998.
Legrand, M., Sciare, J., Jourdain, B., and Genthon, C.: Subdaily variations of atmospheric dimethylsulfide, dimethylsulfoxide, methanesulfonate, and non-sea salt sulfate aerosol in the atmospheric boundary layer at Dumont d'Urville (coastal Antarctica) during summer, J. Geophys. Res., 106, 14409-14422, 2001.

Legrand, M., Preunkert, S., Weller, R., Zipf, L., Elsässer, C., Merchel, S., Rugel, G., and Wagenbach, D.: Year-round record of bulk and size-segregated aerosol composition in central Antarctica (Concordia site) - Part 2: Biogenic sulfur (sulfate and methanesulfonate) aerosol, Atmos. Chem. Phys., 17, 1405514073, https://doi.org/10.5194/acp-17-14055-2017, 2017 a.

Legrand, M., Preunkert, S., Wolff, E., Weller, R., Jourdain, B., and Wagenbach, D.: Year-round records of bulk and sizesegregated aerosol composition in central Antarctica (Concordia site) - Part 1: Fractionation of sea-salt particles, Atmos. Chem. Phys., 17, 14039-14054, https://doi.org/10.5194/acp-17-140392017, $2017 \mathrm{~b}$.

Mauldin III, R. L., Kosciuch, E., Henry, B., Eisele, F. L., Shetter, R., Lefer, B., Chen, G., Davis, D., Huey, G., and Tanner, D.: Measurements of $\mathrm{OH}, \mathrm{HO}_{2}+\mathrm{RO}_{2}, \mathrm{H}_{2} \mathrm{SO}_{4}$, and MSA at the South Pole during ISCAT 2000, Atmos. Environ., 38, 54235437, 2004.

Mayewski, P. A., Meredith, M. P., Summerhayes, C. P., Turner, J., Worby, A., Barrett, P. J., Casassa, G., Bertler, N. A. N., Bracegirdle, T., Naveira Garabato, A. C., Bromwich, D., Campell, H., Hamilton, G. S., Lyons, W. B., Maasch, K. A., Aoki, S., Xiao, C., and van Ommen, T.: State of the Antarctic and southern ocean climate system, Rev. Geophys., 47, RG1003, https://doi.org/10.1029/2007RG000231, 2009.

Meskhidze, N. and Nenes, A.: Phytoplankton and Cloudiness in the Southern Ocean, Science, 314, 1419-1423, https://doi.org/10.1126/science.1131779, 2006.

Metzger, A., Verheggen, B., Dommen, J., Duplissy, J., Prevot, A. S. H., Weingartner, E., Riipinen, I., Kulmala, M., Spracklen, D. V., Carslaw, K. S., and Baltensperger, U.: Evidence for the role of organics in aerosol particle formation under atmospheric conditions, P. Natl. Acad. Sci. USA, 107, 6646-6651, https://doi.org/10.1073/pnas.0911330107, 2010.

Minikin, A., Legrand, M., Hall, J., Wagenbach, D., Kleefeld, C., Wolff, E., Pasteur, E. C., and Ducroz, F.: Sulfur-containing species (sulfate and methanesulfonate) in coastal Antarctic aerosol and precipitation, J. Geophys. Res., 103, 10975-10990, 1998.

Nieminen, T., Lehtinen, K. E. J., and Kulmala, M.: Sub-10 nm particle growth by vapor condensation - effects of vapor molecule size and particle thermal speed, Atmos. Chem. Phys., 10, 9773 9779, https://doi.org/10.5194/acp-10-9773-2010, 2010.

Oerter, H., Drücker, C., Kipfstuhl, S., and Wilhelms, F.: Kohnen Station - the Drilling Camp fort the EPICA Deep Ice Core in Dronning Maud Land, Polarforschung, 78, 1-23, https://doi.org/10.2312/polarforschung.78.1-2.1, 2009.

Pant, V., Siingh, D., and Kama, A. K.: Concentrations and size distributions of aerosol particles at Maitri during the passage of cyclonic storms revolving around the continent of Antarctica, J. Geophys. Res., 115, D17202, https://doi.org/10.1029/2009JD013481, 2010.

Park, J., Sakurai, H., Vollmers, K., and McMurry, P. H.: Aerosol size distributions measured at South 
Pole during ISCAT, Atmos. Environ., 38, 5493-5500, https://doi.org/10.1016/j.atmosenv.2002.12.001, 2004.

Piel, C.: Variabilität physikalischer und chemischer Parameter des Aerosols in der antarktischen Troposphäre, $\mathrm{PhD}$ thesis, Reports on Polar and Marine Research, 476, edited by: Riemann, F., Alfred-Wegener-Inst. for Polar and Marine Res., Bremerhaven, Germany, 88 pp., 2004.

Piel, C., Weller, R., Huke, M., and Wagenbach, D.: Atmospheric methane sulfonate and non-sea salt sulfate records at the EPICA deep-drilling site in Dronning Maud Land, Antarctica, J. Geophys. Res., 111, D03304, https://doi.org/10.1029/2005JD006213, 2006.

Powers, J. G., Monaghan, A. J., Cayette, A. M., Bromwich, D. H., Kuo, Y.-H., and Manning, K. W.: Real-time mesoscale modelling over Antarctica the Antarctic Mesoscale Prediction System, B. Am. Meteorol. Soc., 84, 1533-1545, 2003.

Preunkert, S., Jourdain, B., Legrand, M., Udisti, R., Becagli, S., and Cerri, O.: Seasonality of sulfur species (dimethyl sulphide, sulfate, and methanesulfonate) in Antartica: Inland versus coastal regions, J. Geophys. Res., 113, D15302, https://doi.org/10.1029/2008JD009937, 2008.

Quinn, P. K. and Bates, T. S.: The case against climate regulation via oceanic phytoplankton sulphur emissions, Nature, 480, 5156, https://doi.org/10.1038/nature10580, 2011.

Raes, F., Van Dingenen, R., Vignati, E., Wilson, J., Putaud, J.-P., Seinfeld, J. H., and Adams, P.: Formation and cycling of aerosols in the global troposphere, Atmos. Environ., 34, 4215-4240, 2000.

Rankin, A. M. and Wolff, E. W.: A year-long record of sizesegregated aerosol composition at Halley, Antarctica, J. Geophys. Res., 108, 4775, https://doi.org/10.1029/2003JD003993, 2003.

Rosenfeld, D., Andreae, M. O., Asmi, A., Chin, M., de Leeuw, G., Donovan, D. P., Kahn, R., Kinne, S., Kivekäs, N., Kulmala, M., Lau, W., Schmidt, K. S., Suni, T., Wagner, T., Wild, M., and Quaas, J.: Global observations of aerosol-cloudprecipitation-climate interactions, Rev. Geophys., 52, 750-808, https://doi.org/10.1002/2013RG000441, 2014.

Russell, L. M., Lenschow, D. H., Laursen, K. K., Krummel, P. B., Siems, S. T., Bandy, A. R., Thornton, D. C., and Bates, T. S.: Bidirectional mixing in an ACE 1 marine boundary layer overlain by a second turbulent layer, J. Geophys. Res., 103, 16411-16432, 1998.

Schlosser, E., Manning, K. W., Powers, J. G., Duda, M. G., Birnbaum, G., and Fujita, K.: Characteristics of high-precipitation events in Dronning Maud Land, Antarctica, J. Geophys. Res., 115, D14107, https://doi.org/10.1029/2009JD013410, 2010.

Seinfeld, J. H., Bretherton, C., Carslaw, K. S., Coe, H., DeMott, P. J., Dunlea, E. J., Feingold, G., Ghan, S., Guenther, A. B., Kahn, R., Kraucunas, I., Kreidenweis, S. M., Molina, M. J., Nenes, A., Penner, J. E., Prather, K. A., Ramanathan, V., Ramaswamy, V., Rasch, P. J., Ravishankara, A. R., Rosenfeld, D., Stephens, G., and Wood, R: Improving our fundamental understanding of the role of aerosol-cloud interactions in the climate system, P. Natl. Acad. Sci. USA, 113, 5781-5790, https://doi.org/10.1073/pnas.1514043113, 2016.

Stohl, A.: Computation, accuracy and applications of trajectories a review and bibliography, Atmos. Environ., 32, 947-966, 1998.
Teinilä, K., Kerminen, V.-M., and Hillamo, R.: A study of sizesegregated aerosol chemistry in the Antarctic atmosphere, J. Geophys. Res., 105, 3893-3904, 2000.

Teinilä, K., Frey, A., Hillamo, R., Tülp, H. C., and Weller, R.: A study of the sea-salt chemistry using size-segregated aerosol measurements at coastal Antarctic station Neumayer, Atmos. Environ., 96, 11-19, 2014.

Tröstl, J., Chuang, W. K., Gordon, H., Heinritzi, M., Yan, C., Molteni, U., Ahlm, L., Frege, C., Bianchi, F., Wagner, R., Simon, M., Lehtipalo, K., Williamson, C., Craven, J. S., Duplissy, J., Adamov, A., Almeida, J., Bernhammer, A.-K., Breitenlechner, M., Brilke, S., Dias, A., Ehrhart, S., Flagan, R. C., Franchin, A., Fuchs, C., Guida, R., Gysel, M., Hansel, A., Hoyle, C. R., Jokinen, T., Junninen, H., Kangasluoma, J., Keskinen, H., Kim, J., Krapf, M., Kürten, A., Laaksonen, A., Lawler, M., Leiminger, M., Mathot, S., Möhler, O., Nieminen, T., Onnela, A., Petäjä, T., Piel, F. M., Miettinen, P., Rissanen, M. P., Rondo, L., Sarnela, N., Schobesberger, S., Sengupta, K., Sipilä, M., Smith, J. N., Steiner, G., Tomè, A., Virtanen, A., Wagner, A. C., Weingartner, E., Wimmer, D., Winkler, P. M., Ye, P., Carslaw, K. S., Curtius, J., Dommen, J., Kirkby, J., Kulmala, M., Riipinen, I., Worsnop, D. R., Donahue, N. M., and Baltensperger, U.: The role of low-volatile organic compounds in initial particle growth in the atmosphere, Nature, 533, 527-531, https://doi.org/10.1038/nature18271, 2016.

Van As, D., van den Broeke, M., and Helsen, M. M.: Structure and dynamics of the summertime atmospheric boundary layer over the Antarctic Plateau: 1. Measurements and model validation, J. Geophys. Res., 111, D07102, https://doi.org/10.1029/2005JD005948, 2006.

Virkkula, A., Hirsikko, A., Vana, M., Aalto, P. P., Hillamo, R., and Kulmala, M.: Charged particle size distributions and analysis of particle formation events at the Finnish Antarctic research station Abao, Boreal Environ. Res., 12, 397-408, 2007.

Wang, S. C. and Flagan, R. C.: Scanning Electrical Mobility Spectrometer, Aerosol Sci. Tech., 13, 230-240, 1990.

Welker, C., Martius, O., Froidevaux, P., Reijmer, C. H., and Fischer, H.: A climatological analysis of high-precipitation events in Dronning Maud Land, Antarctica, and associated large-scale atmospheric conditions, J. Geophys. Res.-Atmos., 119, 11932 11954, https://doi.org/10.1002/2014JD022259, 2014.

Weller, R. and Wagenbach, D.: Year-round chemical aerosol records in continental Antarctica obtained by automatic samplings, Tellus B, 59, 755-765, https://doi.org/10.1111/j.16000889.2007.00293.x, 2007.

Weller, R., Minikin, A., Wagenbach, D., and Dreiling, V.: Characterization of the inter-annual, seasonal, and diurnal variations of condensation particle concentrations at Neumayer, Antarctica, Atmos. Chem. Phys., 11, 13243-13257, https://doi.org/10.5194/acp-11-13243-2011, 2011.

Weller, R., Levin, I., Schmithüsen, D., Nachbar, M., Asseng, J., and Wagenbach, D.: On the variability of atmospheric ${ }^{222} \mathrm{Rn}$ activity concentrations measured at Neumayer, coastal Antarctica, Atmos. Chem. Phys., 14, 3843-3853, https://doi.org/10.5194/acp14-3843-2014, 2014.

Weller, R., Schmidt, K., Teinilä, K., and Hillamo, R.: Natural new particle formation at the coastal Antarctic site Neumayer, Atmos. Chem. Phys., 15, 11399-11410, https://doi.org/10.5194/acp-1511399-2015, 2015. 
Weller, R., Legrand, M., and Preunkert, S.: Size distribution and ionic composition of marine summer aerosol at the continental Antarctic site Kohnen, https://doi.org/10.1594/PANGAEA.882375, 2017.

Winklmayr, W., Wang, H.-C., and John, W.: Adaption of the Twomey Algorithm to the Inversion of Cascade impactor Data, Aerosol Sci. Tech., 13, 322-331, 1990.

Wolff, E. W., Fischer, H., Fundel, F., Ruth, U., Twarloh, B., Littot, G. C., Mulvaney, R., Röthlisberger, R., de Angelis, M., Boutron, C. F., Hansson, M., Jonsell, U., Hutterli, M. A., Lambert, F., Kaufmann, P., Stauffer, B., Stocker, T. F., Steffensen, J. P., Bigler, M., Siggaard-Andersen, M. L., Udisti, R., Becagli, S., Castellano, E., Severi, M., Wagenbach, D., Barbante, C., Gabrielli, P., and Gaspari, V.: Southern Ocean sea-ice extent, productivity and iron flux over the past eight glacial cycles, Nature, 440, 491-496, https://doi.org/10.1038/nature04614, 2006.
Yli-Juuti, T., Nieminen, T., Hirsikko, A., Aalto, P. P., Asmi, E., Hõrrak, U., Manninen, H. E., Patokoski, J., Dal Maso, M., Petäjä, T., Rinne, J., Kulmala, M., and Riipinen, I.: Growth rates of nucleation mode particles in Hyytiälä during 20032009: variation with particle size, season, data analysis method and ambient conditions, Atmos. Chem. Phys., 11, 12865-12886, https://doi.org/10.5194/acp-11-12865-2011, 2011. 